\title{
Chapter 1.5
}

\section{ANTI-VIRAL APPROACHES AGAINST INFLUENZA VIRUSES}

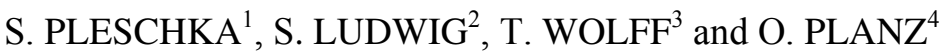 \\ ${ }^{I}$ Institute of Medical Virology, Justus-Liebig-University, Frankfurter Str. 107, D-35392 \\ Gießen, Germany; ${ }^{2}$ Institute of Molecular Virology (IMV), ZMBE, Westfälische-Wilhelms- \\ Universität, Von-Esmarch Str. 56, D-48149 Münster, Germany; Robert-Koch-Institute (RKI), \\ Nordufer 20, D-13353 Berlin, Germany; ${ }^{4}$ Friedrich-Loeffler-Institute (FLI), Paul-Ehrlich Str. \\ 28, D-72076 Tübingen, Germany
}

\begin{abstract}
Influenza viruses are a continuous and severe global threat to mankind and many animal species. The re-emerging disease gives rise to thousands of deaths and enormous economic losses each year. The devastating results of the recent outbreaks of avian influenza in Europe and south East Asia demonstrate this immanent danger. The major problem in fighting the flu is the high genetic variability of the virus. This results in the rapid formation of variants that escape the acquired immunity against previous virus strains or confer resistance to anti-viral agents. Despite successful vaccination against circulating strains causing annual epidemics the number of admitted measures to fight acute infection in risk patients is limited and quarantine is of limited help as the virus transmitted before onset of symptoms. This poses an even greater challenge when a completely new virus should hit the human population without preexisting immunity and start a pandemic. Therefore the development of effective drugs against viral functions or essential cellular activities supporting viral replication is of outmost importance today.
\end{abstract}

\section{INTRODUCTION}

Influenza is a highly contagious, acute respiratory disease with global significance that affects all age groups and can occur repeatedly in any individual. The etiological agent of the disease, influenza virus is responsible for an average between three and five Mill. cases of severe influenza leading 
to about 250,000-500,000 mortalities annually in the industrialized world according to WHO estimations. Compared to otherwise healthy persons, death rates in patients of risk groups (s. 2.4) are 50-100 fold higher in patients with cardiovascular or pulmonary disease as compared to healthy individuals. Annual health cost, costs, e.g. due to work absenteeism (also related to parental care of infected children) or costs related to death, increased disabilities etc. can be higher than 40 Mil. $€$ in European countries. Furthermore. For a pandemic outbreak the Centers for Disease Control (CDC) estimates that in the USA that $85 \%$ of all death will be caused by $15 \%$ of the population which are at high-risk. This will result in a financial burden of up to 166.5 billion US\$ not including the commercial impact. The death rate would be up to 207,000 accompanied by up to 734,000 hospitalizations, 18-42 million outpatient visits and 20-47 million additional illnesses (Cox et al., 2004; Wilschut and McElhaney, 2005). This clearly would overrun the capacity of current supply and management of vaccines available.

Since waterfowl represents the natural reservoir for the virus (Lamb and Krug, 2001; Webster, 1999; Wilschut and McElhaney, 2005; Wright and Webster, 2001) and many other animal species can be infected, the eradication of the virus is impossible and a constant reemergence of the disease will continue to occur. Epidemics appear almost annually and are due to an antigenic change of the viral surface glycoproteins (Fig. 1). Furthermore, highly pathogenic strains of influenza-A-virus have emerged unpredictably but repeatedly in recent history as pandemics like the "Spanish-Flu" that caused the death of 20-40 millions people worldwide (Taubenberger et al., 2000; Webster, 1999). Since these pandemic virus strains usually possess different antigenic characteristics, current vaccines will be ineffective once such a virus emerges. Regarding the vast possibilities for such a strain to "travel" around the world (Hufnagel et al., 2004) it becomes evident that effective countermeasures are required for the fight against these foes. In recent outbreaks of avian viruses that infected humans (1997, 1999, 2003/4/5) (Chen et al., 2004; Hatta and Kawaoka, 2002; Li et al., 2004) from a total of 108 confirmed cases 54 people died (07/2005) (World Health Organization, 2005). Fortunately, until now these particular viruses have not acquire the ability to spread in the human population. However, any novel virus strain emerging in the future may have such a capability (Webby and Webster, 2003).

Here, we give an overview of current and new anti-influenza strategies, such as immunization methods and drugs against the virus. Since every virus depends on its host cell, cellular functions essential for viral replication may also be suitable targets for anti-viral therapy. In this respect intra-cellular 
signaling cascades activated by the virus, in particular MAPK pathways, have recently come into focus (Ludwig et al., 2003; Ludwig et al., 1999).

\section{THE VIRUS AND ITS REPLICATION}

\section{$2.1 \quad$ Viral components}

Influenza viruses belong to the order of the Orthomyxoviridae. They possess a segmented, single stranded RNA-genome with negative orientation. They are divided into three types, A, B and C based on genetic and antigenic differences. Among the three types influenza-A-viruses are clinically the most important pathogens since they have been responsible for severe epidemics in humans and domestic animals in the past. Thus the focus of this chapter will be on type-A influenza viruses. A detailed description of the viral proteins and the replication cycle of influenza-A-viruses can be found elsewhere (Lamb and Krug, 2001; Wright and Webster, 2001). Therefore we will only give a brief overview on these topics without referring to individual references.

The influenza-A-virus particle is composed of a lipid envelope derived from the host cell and of 9-10 structural virus proteins (Figure 1 and Table 1). The components of the RNA-dependent RNA-polymerase complex (RDRP), $\mathrm{PB} 2, \mathrm{~PB} 1$ and PA are associated with the ribonucleoprotein complex (RNP) and are encoded by the vRNA segments 1-3. The PB1 segment of many, but not all, influenza-A-virus strains also contains a +1 -reading frame encoding the recently discovered PB1-F2 protein (Chen et al., 2001). The viral surface glycoproteins hemagglutinin (HA) and neuraminidase (NA) are expressed from vRNA segments 4 and 6 , respectively. The nucleoprotein (NP) is encoded by segment 5 and associates with the vRNA segments. It is the major component of the RNPs. The two smallest vRNA segments each code for two proteins. The matrix protein (M1) is colinear translated from the mRNA of segment 7 and forms an inner layer within the virion. A spliced version of the mRNA gives rise to a third viral transmembrane component, the M2 protein, which functions as a pH-dependent ion channel. Employing a similar coding strategy segment 8 harbors the sequence information for the nonstructural NS1 protein and the nuclear export protein NS2/NEP. NS2/NEP is a minor component of the virion and is found associated with the $\mathrm{M} 1$ protein. 


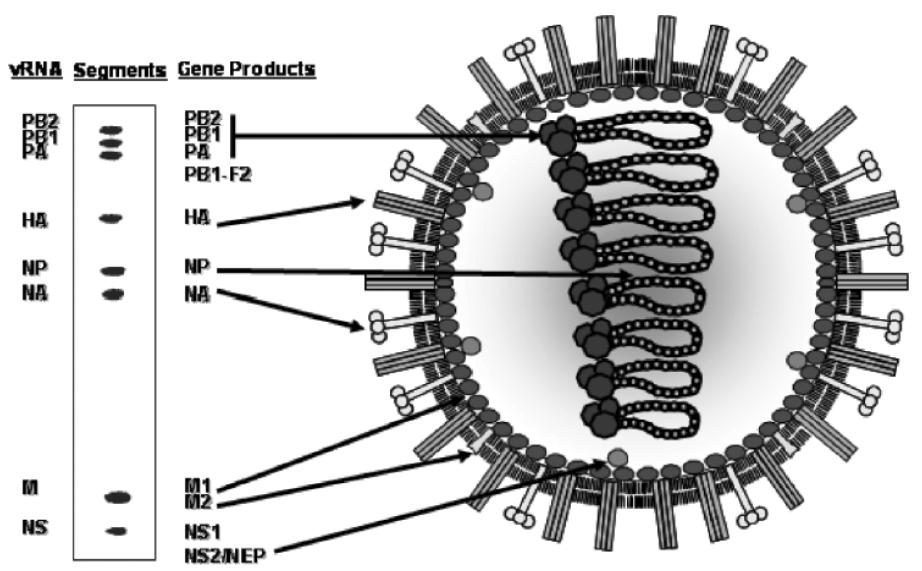

Figure 1. The InFLUENZA-A-VIRUS PARTICLE Schematic representation of the spherical influenza-A-virus particle that has a diameter of about $100 \mathrm{~nm}$. The eight viral RNA segments were separated by urea-polyacrylamide gel electrophoresis and visualized by silver staining (left). The corresponding gene products and their presumed location in the virus particle are indicated (right). NS1 is not a structural part of the mature virion. For details see text.

Table 1 summarizes details of the genome segments, the encoded viral proteins and their according function.

Table 1. Influenza-A-virus Genome (strain A/PR/8/34)

\begin{tabular}{|c|c|c|c|l|}
\hline Segment & vRNA & Protein & AA & \multicolumn{1}{|c|}{ Function(s) } \\
\hline 1 & 2341 & PB2 & 759 & $\begin{array}{l}\text { Subunit of viral RNA polymerase; cap- } \\
\text { binding }\end{array}$ \\
\hline 2 & 2341 & PB1 & 757 & $\begin{array}{l}\text { Catalytic subunit of viral RNA } \\
\text { polymerase } \\
\text { Pro-apoptotic activity }\end{array}$ \\
\hline 3 & 2233 & PA & 716 & Subunit of viral RNA polymerase \\
\hline 4 & 1778 & HA & 566 & $\begin{array}{l}\text { Surface glycoprotein; receptor binding, } \\
\text { membrane fusion }\end{array}$ \\
\hline 5 & 1565 & NP & 498 & $\begin{array}{l}\text { Nucleoprotein; encapsidation of viral } \\
\text { genomic and anti-genomic RNA }\end{array}$ \\
\hline 6 & 1413 & NA & 454 & Neuraminidase \\
\hline 7 & 1027 & M1 & 252 & Matrixprotein \\
\hline 8 & 890 & M2 & 97 & $\begin{array}{l}\text { Ion channel activity, protecting HA } \\
\text { conformation }\end{array}$ \\
\hline & & NS1 & 230 & $\begin{array}{l}\text { Regulation of viral RDRP activity } \\
\text { Interferon antagonist; } \\
\text { Enhancer of viral mRNA translation; } \\
\text { inhibition of (i) pre-mRNA splicing, } \\
\text { (ii) cellular mRNA-polyadenylation, } \\
\text { (iii) PKR activity, }\end{array}$ \\
\hline & & & Nuclear export factor \\
\hline
\end{tabular}




\subsection{The influenza replication cycle}

The viral replication cycle is initiated by binding of the HA to sialic-acid (neuraminic acid) containing cellular receptors and subsequent endocytosis of the virus (Figure 2) (For references: (Lamb and Krug, 2001; Wright and Webster, 2001)). The active HA molecule consists of two subunits $\left(\mathrm{HA}_{1} /\right.$ $\mathrm{HA}_{2}$ ) derived from the uncleaved precursor $\mathrm{HA}_{0}$, which becomes proteolytically processed after release of the virion by extra-cellular proteases. This cleavage is absolutely essential for HA-function and cell infection. Virus disassembly occurs in the acidic environment of late endosomal vesicles and involves two crucial events. First, the conformation of the HA is changed to a low-pH form, which results in exposure of a fusion active protein sequence within the $\mathrm{HA}_{2}$. This fusion peptide is thought to contact the endosomal membrane and to initiate fusion with the viral envelope. Second, the low $\mathrm{pH}$ in the endosomes activates the viral M2 ion channel protein resulting in a flow of protons into the interior of the virion. Acidification facilitates dissociation of the RNPs from the M1 protein. The RNPs are subsequently released into the cytoplasm and rapidly imported into the nucleus through the nuclear pore complexes. The viral genomic segments are replicated and transcribed by the viral RDRP associated with the RNPs in the nucleus of the infected cell. The vRNA is directly transcribed to mRNA and, in addition, serves as a template for a complementary copy (cRNA), which itself is the template for new vRNA. In the late phase of infection newly synthesized viral RNPs are exported to the cytoplasm. NS1 protein functions as a regulatory factor in the virus infected cell. The NA, the $\mathrm{M} 2$ and the precursor $\mathrm{HA}\left(\mathrm{HA}_{0}\right)$ proteins follow the exocytotic transport pathway from the rER via the Golgi complex and the trans Golgi network. The mature HA and NA glycoproteins and the nonglycosylated M2 are finally integrated into the plasma membrane as trimers (HA) or tetramers (NA, M2), respectively.

M1 assembles in patches at the cell membrane. It is thought to associate with the glycoproteins (HA and NA) and to recruit the RNPs to the plasma membrane in the late phase of the replication cycle. Finally the viral RNPs become enveloped by a cellular bilipid layer carrying the HA, NA and M2 proteins resulting in budding of new virus particles from the apical cell surface. 


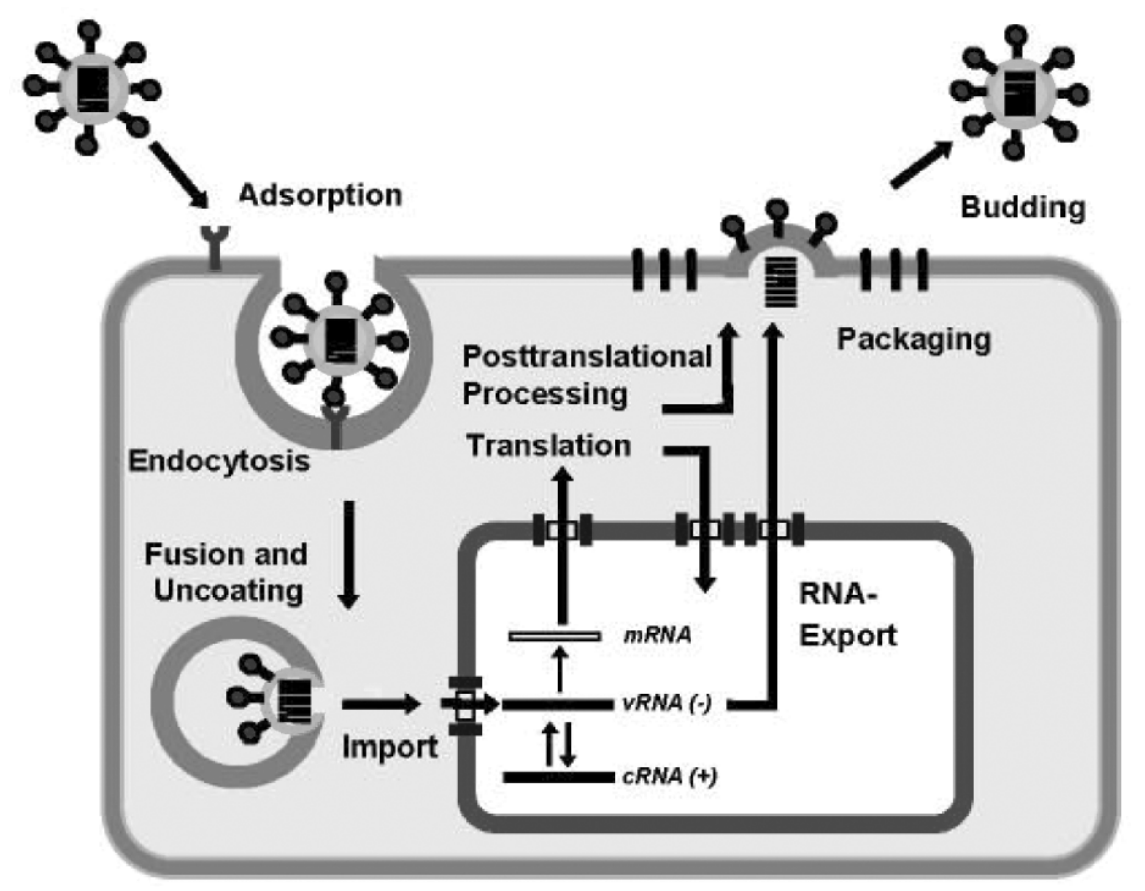

Figure 2. THE REPLICATION CYCLE OF INFLUENZA VIRUSES The virion attaches to the cellular receptor determinant. The receptor-bound particle enters the cell via endocytosis. After fusion of the viral and the endosomal membrane the viral genome is released into the cytoplasm. The RNPs are transported into the nucleus where replication and transcription of the viral RNA segments occurs. The mRNAs are exported into the cytoplasm and are translated into viral proteins. The viral glycoproteins enter the exocytotic transport pathway to the cell surface. Replicative viral proteins enter the nucleus to amplify the viral genome. In the late stage of the infection cycle newly synthesized RNPs are exported from the nucleus and are assembled into progeny virions that bud from the cell surface.

\subsection{Antigenic drift and antigenic shift}

The polymerase complex of influenza viruses does not possess a proof reading activity, thus numerous mutations accumulate in the viral genome during ongoing replication (Lamb and Krug, 2001) leading to changes in all proteins. This includes conformational alteration of HA- and NA-epitopes against which neutralizing antibodies are generated. Influenza-A-viruses are categorized by antigenic differences of the HA- and NA-proteins. The high mutation rate combined with the high replication rate results in a multitude of new variants produced in each replication cycle, thus allowing the virus to rapidly adapt to changes in the environment. This results in an escape of the 
existing immunity and in resistance to drugs acting directly against viral functions. Gradual changes of the antigenic properties that make existing vaccines less or non effective are described as antigenic drift and demand for new compositions of the yearly vaccines.

Due to the nature of their segmented genome influenza virus can independently recombine segments upon the infection of a cell with two different viruses. This is described as genetic reassortment. Today 16 HAsubtypes (H1-H16) and 9 NA-subtypes (N1-N9) are known, which can mix and lead to new antigenic properties. (Lamb and Krug, 2001; Webster et al., 1992; Wright and Webster, 2001). Not all combination will ultimately be advantageous, but can lead to the generation of a virus that combines the ability to replicate in humans with novel antigenic properties (antigenic shift). This has happened at least three times in the last century resulting in the pandemics of 1918 ("Spanish Flu"), 1957 ("Asian Flu") and 1968 ("Hong Kong Flu") that caused up to 40 million death. Therefore, the question is not "if" but "when" will such a pandemic occur again (Horimoto and Kawaoka, 2001; Webby and Webster, 2003; Webster, 1997b). A vaccine against such "new" viruses can not be generated in advance and as vaccine production would need significantly more time than it takes for a pandemic virus to spread around the world (Hufnagel et al., 2004), alternative weapons in the fight against these enemies are urgently needed. Besides pandemic variants that can occur when human and avian influenza virus reassort in porcine hosts (regarded as "mixing vessels") (Webster, 1997a; Webster et al., 1995; Webster et al., 1997), avian influenza virus strains have directly infected humans, as happened in Hong Kong in 1997 (Claas et al., 1998; de Jong et al., 1997; Subbarao et al., 1998) and recently (2004/2005) (Fouchier et al., 2004; Koopmans et al., 2004) during vast outbreaks of avian influenza. These viruses show an extremely high virulence in humans with case fatality rates up to $70 \%$.

\subsection{The disease}

The virus that normally causes a respiratory disease (for references: (Wilschut and McElhaney, 2005)) is transmitted by aerosol droplets and contaminated hands and can already be shed before onset of symptoms (Cox et al., 2004). Therefore, high population density and dry air leading to reduced protection of respiratory epithelium by the mucus are conditions that promote transmission of the virus.

The infection with influenza viruses is normally limited to the respiratory tract. Here proteases released by Clara cells in the epithelium are present that activate the HA to allow further infections (s. 2.2) (for review (Ludwig et al., 
1999)). Innate immunity as well as the adaptive immune system will normally restrict virus propagation. Therefore population groups, that have a less protective immune system, such as young children up to two years and older persons over 65 as well as immunocompromised or chronically diseased persons are especially of risk. The replication of the virus leads to the lysis of the epithelial cells and enhanced mucus production causing running nose and cough. Furthermore, inflammation and oedema at the replication site are due to cytokines released. This can lead to fever and related symptoms. Bacterial super-infections of the harmed tissue can further complicate the situation. Normally onset of systemic (fever, myaglia, headaches, severe malaise) and respiratory (coughing, sore throat, rhinitis) symptoms occur after about two days incubation period and can last for about seven to ten days. Coughing and overall weakness can persist for up to two weeks. If the virus spreads from the bronchiolar tract to the aveolars, viral pneumonia and interstitial pneumonitis with mononuclear and haemorrhage infiltration and finally lysis of the inter-aveolar space is possible (Wilschut and McElhaney, 2005).

This scenario is a likely picture in case of infection with a pandemic influenza strain, where the individual has not had a prior exposure to the virus and the innate immunity reaction can lead to a strong immunpathogenesis. High virus replication will induce secretion of large quantities of cytokines by the infected epithelia and will stimulate inflammatory processes. Together with the destruction of the epithelia this results in an influx of fluid into the aveolars leading to hypoxia and acute respiratory distress syndrome, that may cause the death within a short period of time (12 days after onset). This scenario might also be caused by additional viral factors enhancing pathogenicity. Such factors that are yet not well defined probably have contributed to the devastating outcome of the "Spanish Flu" (Wilschut and McElhaney, 2005).

Accurate and rapid diagnosis of the disease is essential for an effective treatment, especially with anti-viral substances, as virus replication and therefore illness progresses rapidly. Samples can be tested serologically, by cell culture or RT-PCR for strain typing and should be done within four days after onset of symptoms (Wilschut and McElhaney, 2005).

\section{TARGETING THE VIRUS}

There are two main methods of influenza prophylaxis: the use of antiviral drugs and vaccines. Several drugs are available for influenza prophylaxis functioning either as M2-ion channel inhibitors (amantadine and 
rimantadine) or as inhibitors of the NA (zanamivir and oseltamivir). Despite these anti-viral drugs, which are a useful adjunct to influenza vaccines, vaccination itself remains the cornerstone of prophylaxis. Vaccination induces a good degree of protection and is in general well tolerated by the recipient. Nevertheless, while resistant virus variants can emerge after antiviral drug treatment the disadvantage of vaccination is that immunization needs to be refreshed almost every year, since the vaccine must reformulated to take account of the changing virus.

\subsection{Host immunity: old and new vaccine approaches}

In the immune response to influenza infection both the humoral and cell mediated immunity are involved. From the side of the humoral immune system, both the mucosal and the systemic immunity contribute to resistance to influenza infection. The cellular immune response is involved in recovery from influenza virus infection by eliminating virus-infected cells and by providing help for antibody production (Cox et al., 2004; Woodland et al., 2001). Consequently, the humoral immune response is the primary target of vaccination. After influenza virus infection antibodies directed against all major viral proteins can be detected in humans and the level of serum antibodies correlate with resistance to disease (Couch, 2003; Couch and Kasel, 1983; Coulter et al., 2003; Nichol et al., 1998; Potter and Oxford, 1979). Only antibodies specific for the surface glycoproteins HA and NA are associated with resistance to infection. In contrast, antibodies to the conserved internal antigens $\mathrm{M}$ and NP are not protective (de Jong et al., 2003; Tamura and Kurata, 2004). The mucosal tissues of the respiratory system are the main portal entry of influenza virus and consequently the mucosal immune system functions as the first line of defense against infection apart from innate immunity (see paragraph 4). Antibodies secreted locally in the upper respiratory tract are a major factor in resistance to natural infection. Secretory immunoglobulin A (SIgA) and to some extent $\operatorname{IgM}$ are the major neutralizing antibodies directed against the entering virus. Furthermore, these antibodies can function intra-cellular to inhibit influenza replication. IgA and IgM are involved in protection of the upper respiratory tract while serum IgG acts in protection of the lower respiratory tract (Cox et al.,2004). An anti-HA antibody response (haemagglutination-inhibition(HI) titre $\geq 40$ ) can be detected in approximately $80 \%$ of subjects after natural influenza virus infection and correlates with protection against the flu. Plasma cells producing all three major Ig classes are present in the peripheral blood in normal subjects (Cox and Subbarao, 1999; LaForce et al., 1994). 
The immune response induced by infection protects against reinfection with the same virus or an antigenically similar viral strain.

Cell mediated immunity plays a role in recovery from influenza virus infection and may also prevent flu-associated complications, but it does not seem to contribute significantly in preventing infection. Influenza specific cellular $\mathrm{T}$ cells have been detected in the blood and the lower respiratory tract secretions of infected subjects (Cox et al., 2004). Influenza virusspecific cytotoxic T-lymphocytes (CTL) regognize both external and internal proteins of virus on infected cells. In humans a major component of this response is directed toward the NP- and M1-protein. Even though influenza virus specific CTL's are not able to protect against the infection, these cells are important for the clearance of the virus. Futhermore, cytolysis of influenza virus-infected cells can be mediated by influenza virus-specific antibodies and complement (Cox et al., 2004; McMichael et al., 1983; McMichael et al., 1986; Townsend et al., 1989). CD4+ T cells function as helper cells for antibody production. Moreover, it is suggested, that CD4 cells might act as direct effectors in protection against influenza virusinfection (Brown et al., 2004).

\subsubsection{Inactivated influenza vaccines}

Inactivated vaccines (IV) are availeble for about 60 years. Because of the antigenic drift observed in influenza HA- and NA-glycoproteins these vaccines need to be matched with the randomly mutating molecular structure of the new occurring "drift" strain. Besides these vaccines there are various new approaches for influenza vaccines in promising developmental stages. These new stratagies include vaccines with immunomodulators, virosomes and DNA-vaccines.

IVs vaccines are administered world wide each year with millions of doses. These vaccines have good safety and tolerance profiles, with very low number of adverse reactions reported. These reactions are tenderness and redness that arise locally at the injection site and are more frequent in healthy $(<50 \%)$ than in elderly recipients $(25 \%)$ (Cox et al., 2004). IVs are produced by propagation of the virus in embryonated chicken eggs. The currently used bacterial endotoxin-free trivalent IVs (TIV) are formulated with $15 \mu \mathrm{g}$ HA each from a current influenza virus $\mathrm{A} / \mathrm{H} 1 \mathrm{~N} 1, \mathrm{~A} / \mathrm{H} 3 \mathrm{~N} 2$, and a $\mathrm{B}$-virus strain. The seed strain is prepared by co-infecting the allantoic sac of the chicken embryo with a laboratory-adapted high-growth phenotype of H1N1 (A/PR/8/34) and the epidemic strain. This results in viral replication and genetic re-assortment leading to high growth reassortants. Thereafter the new hybrid viruses are screened for the absence of genes encoding PR $/ 8$ or PR/8-like surface glycoproteins. The selected seed strain containing HA- and NA-components of the epidemic strain is mass propagated in chicken eggs to 
obtain sufficient quantities of vaccine virus. The allantoic fluid is harvested, and the virus is concentrated and highly purified by zonal centrifugation. As a next step the virus is inactivated. Depending on the nature of inactivation the vaccine is used as whole inactivated vaccine after treatment with formalydehyde or $\beta$-propiolactone or as split vaccine (chemically disrupted by ethyl either or SDS). Furthermore, the vaccine is used as subunit vaccines (purified surface glycoproteins). Even though influenza vaccines have excellent tolerant profiles, since propagation in chicken eggs may lead to contamination of the vaccine with trace amounts of residual egg proteins, they should not be administered to persons who have anaphylactic hypersensitivity to eggs. Whole inactivated influenza vaccine is more immunogenic than split vaccine or subunit vaccine, but is also associated with more frequent side reactions. Consequently, split or subunit are given to children younger than age 9 and two half doses are recommended given at least 1 month apart for naïve persons to develop protective immunity (Bridges et al., 2003). Protection after vaccination against influenza virus infection is dependent on the antigenic match between the vaccine strains and circulating the influenza virus strain. Moreover, protection is also dependent the age and the previous exposition to influenza of the vaccine recipient. If IVs have a good antigenic match they are $60-90 \%$ effective in the prevention of morbidity and mortality among healthy adults (Beyer et al., 2002). In elderly people the effect of protection is reduced to $50-70 \%$ because of decreased immune function. Since the immune system is naïve in young children, they also show a reduction in protection against influenza vaccination (Nichol et al., 1998).

\section{Vaccines with immunopotentiators}

Immunosuppressed individuals, elderly people and subjects with underlying chronic diseases are at increased risk for influenza and related complications. For these people conventional influenza vaccines provide only limited protection. In order to enhance the immune reaction after influenza vaccination, several adjuvants (Latin verb: adjuvare - to help) that function as immunopotentiators have been evaluated.

The liposomal influenza vaccine (INFLUSOME-VAC) consists of liposomes containing the viral surface proteins HA- and NA-derived from various influenza strains and IL-2 or granulocyte-macrophage colonystimulating factor (GM-CSF), as an adjuvant (Babai et al., 2001). In clinical trails with either young adults or elderly vaccination of INFLUSOME-VAC appeared to be both safe and more immunogenic than the currently used vaccine (Ben-Yehuda et al., 2003a; Ben-Yehuda et al., 2003b). Furthermore adjuvant emulsions combined with subunit influenza antigens are in use, such as the "oil in water"-emulsion containing squalene, MF59, (FLUAD). 
This commercially available product was tested in clinical trials in comparison with non-adjuvanted conventional vaccines. Again in elderly individuals the addition of the MF59-adjuvant to subunit influenza vaccines enhances significantly the immune response without causing clinically important changes in the safety profile of the influenza vaccine (Podda, 2001). Other adjuvants that increase immunoreactivity after influenza vaccination are immune stimulating complexes (iscoms). They are $30-40 \mathrm{~nm}$ cage-like structures, which consist of glycoside molecules of the adjuvant Quil A, cholesterol and phospholipids in which the antigen can be integrated. (Osterhaus and Rimmelzwaan, 1998). In animal models, even in the presence of pre-existing antibodies they function as a potent adjuvant system by inducing cellular and humoral immune responses. (Coulter et al., 2003; Rimmelzwaan et al., 2001; Windon et al., 2001).

As mentioned, GM-CSF has a potential role as a vaccine adjuvant. It may enhance the response to vaccination in immunosuppressed individuals. GMCSF stimulates maturation of hematopoietic progenitor cells, induces class II major histocompatibility complex antigen expression on the surface of macrophages, and enhances dendritic cell migration and maturation (Jones et al., 1994). Nevertheless, in various clinical trails with immunosuppressed individuals and cancer patents it was shown, that it is unlikely that GM-CSF improves the immune response (Ramanathan et al., 2002).

\section{Influenza vaccine production in mammalian cells}

For production of influenza vaccines in large-scale cell culture systems several continuous cell lines have been tested for the production of influenza vaccines (Kistner et al., 1998; Pau et al., 2001; Seo et al., 2001; Youil et al., 2004). Production of influenza vaccine in mammalian cell lines has some advantages but also has disadvantages compared to production in chicken egg. (Tree et al., 2001; Youil et al., 2004). Process controllability, scalability and supply of substrates are much easier in cell culture systems. Furthermore, cell culture production reduces the risk of microbial contamination. In contrast, the greatest disadvantage of cell culture based influenza vaccine is the relative low viral yield. On the other hand and a major disadvantage of production in chicken eggs is their supply and possible bacterial contaminations. Additionally the lethality of H5N1 influenza virus to chicken embryos (s. 3.1.3). At the present (2005) two cell line derived vaccines have been licensed in Europe (Kemble and Greenberg, 2003). Estimated time for production of such vaccines is about 6 months. The power of this time gaining approach to generate a great variety of specific influenza-vaccines under controlled safety conditions is achieved by the direct use of field strains (Kistner et al., 1998) as well as seed strains specifically designed by reverse genetics systems and the large scale cell 
culture system. Nevertheless, the application of these techniques largely depends on meeting the needs of high viral yield, appropriate permissiveness, and ability to support replication of all influenza virus strains to high titers in short time (reviewed in: Bardiya and Bae, 2005).

\section{Virosomes}

Immunopotentiating reconstituted influenza virosomes (IRIVs) possess several characteristics defining them as vaccine adjuvants. They are a liposomal carrier system. These reconstituted virus-like particles (VLP; diameter $150 \mathrm{~nm}$ ) contain a lipid bilayer of phosphatidylcholine and phosphatidylethanolamine. HA and NA are intercalated into the lipid bilayer and give the IRIVs their fusogenic activity, but lack the viral genetic material. IRIVs are able to deliver proteins, RNA/DNA and peptides to immunocompetent cells. In addition, virosomes, as vaccine delivery systems, have been shown to be safe and not to engender any antibodies against the phospholipid components. Therefore, their use in vaccination of children and elderly people is recommended. The system is already registered for human use and allows a specific targeting of antigens by a cellular or a humoral immune response. A virosome vaccine, Inflexal- $\mathrm{V}$, is used in Switzerland and Italy. (Gluck et al., 2004; Langley and Faughnan, 2004; Zurbriggen, 2003).

\section{DNA-vaccines}

DNA-vaccines are non-infectious and non-replicative plasmid constructs that encode either only the proteins of interest or the protein of interest in combination with immunomodulatory proteins. This kind of vaccination by direct intra-muscular injection of DNA was first demonstrated in 1990 in a mouse model system et al. (Wolff et al., 1990). Directed intra-muscular DNA-vaccination is not very common. The creation of recombinant influenza vaccines based on DNA-plasmids is more appropriate. With this technique rapid and flexible construction of DNA-plasmid vectors can be achieved, which can address the problems of antigenic drift induced by the circulating influenza virus strain (Ljungberg et al., 2000).

These above described techniques have a potential for the development of live and inactivated vaccines. The efficacy of the plasmid based DNAvaccines expressing the immunogenic influenza virus genes alone or in combination with DNA encoding various cytokines has also been demonstrated in several animal models (for detail see: Bardiya and Bae, 2005). During DNA-vaccination, the foreign genes are endogenously 
expressed in the host, the proteins subsequently processed, and recognized by the immune system of the host. DNA-vaccines elicit a broad-based humoral and cellular immunity against influenza virus proteins (Justewicz et al., 1995). In addition, alterations in the vector, dose of the DNA, inclusion of CpG-ODN motifs, fusion with influenza virus-specific helper T cell or CTL-epitopes, and appropriate vaccine delivery mechanisms will further improve the efficacy of these vaccines (Bowersock and Martin, 1999; Joseph et al., 2002).

\subsubsection{Live vaccines: Cold adapted virus strains and NS1-variants}

An alternative to IVs are attenuated "live" vaccines such as cold-adapted vaccines (CAV: CAIV-T, FluMist ${ }^{\circledR}$ ) and NS1-defective strains used as intranasal influenza vaccine, that may lead to long-lasting, broader immune response (humoral and cellular) that resembles more closely the natural immunity derived from viral infection. For example, CTLs, which are important for the clearance of the virus are activated during an productive infection (Cox et al., 2004). Additional cytokines produced by the infected cells during the innate immunity response enhance and support reaction of the humoral system. Compared to IVs, that are strain- and subtype-specific the CAVs (that also have to be adapted to circulating strains) can provide a broader immunity against circulating viruses (Belshe et al., 2000; King et al., 1998; Nichol, 2001; Stepanova et al., 2002; Treanor et al., 1999; Wareing and Tannock, 2001).

CAVs that already have been used successfully in Russia and are now licensed in the USA (Cox et al., 2004; Kendal, 1997) can be administered intra-nasally for example as aerosols (Abramson, 1999). This results in a limited viral replication in the upper and lower respiratory tract and circumvents the need for syringes. It also supports protective mucosal immunity, which is an important property of nasally applied live influenza virus vaccines. For the generation of a CAV a donor and a wild type strain are reassorted in such a way, that the HA- and NA-segments are wild type (wt) derived and the remaining six segments originate from the donor strain. For this purpose two master strains are currently used as donors in the USA. One to generate A-type and one B-type influenza CAVs (Mendelman et al., 2001; Murphy and Coelingh, 2002). These strains are cold adapted $\left(25^{\circ} \mathrm{C}\right)$ (Kendal, 1997; Maassab and Bryant, 1999) and therefore temperature sensitive (ts) and attenuated, meaning that these viruses will not propagate efficiently at body temperatures. To prevent easy reversion of the genetic markers, that encode the ts-defect and allowing the virus to regain full virulence, all six donor-derived segments carry mutations. 
For the production of such CAV strains embryonated eggs are infected with both viruses (wild type and donor strain) under the selection of antibodies directed against the HA and NA of the donor strain. The attenuated donor strain by itself is unable to cause significant illness in humans, but is able to donate the HA- and NA-proteins of the contemporary epidemic strain to produce live attenuated vaccine by the traditional egg-based process (Belshe, 2004; Clements and Murphy, 1986; Jin et al., 2003). The live attenuated vaccines were shown to be safe and effective in the general population (Belshe et al., 2004; Kendal, 1997; Langley and Faughnan, 2004). CAV are trivalent like the IVs and are composed according to the WHO recommendations (Mendelman et al., 2001). New possibilities of reverse genetic techniques will certainly improve production of vaccine strains in time and quality (s. 3.1.3).

Even though one should consider the possibility of reassortment with another human strain in the vaccinated person, which could produce an aggressive virus, CAVs have been successfully used in Russia without reports of severe side effects and seem to be safe. They show a comparable effectiveness to trivalent IV's (TIVs) and both vaccines can also be used in combination (Belshe et al., 1998; Belshe et al., 2004; Boyce and Poland, 2000; Edwards et al., 1994; Glezen, 2004; Jackson et al., 1999; Mendelman et al., 2001; Swierkosz et al., 1994; Treanor and Betts, 1998; Treanor et al., 1992).

In addition to the traditional live attenuated vaccines, production by reverse genetics (s. 3.1.3) of replication-incompetent influenza virus-like particles (VLPs) by deletion of either the entire NS gene (encoding both the NS1 and NS2 protein) or only the NS2 gene has also been reported. These VLPs were entirely produced from cDNAs (Watanabe et al., 2002b). Although, these technologies are in the very early stages of development and so far only tested in animal models, the VLP incapable of replication and spread to other cells due to deletion of a major protion of the NS1 or M2, are expected to be good novel influenza vaccine candidates (Galarza et al., 2005; Watanabe et al., 2002a). A variation of the theme is presented by influenza virus strains (generated by reverse genetics (s. 3.1.3)) that express a modified NS1 (Palese and Garcia-Sastre, 2002; Palese et al., 1999; Talon et al., 2000). This non-structural protein is the major viral interferon (IFN)antagonist (s. Tab. 1). Even though NS1 is a multifunctional viral protein that supports viral replication it seems to be an accessory protein as a virus without the NS1-gene can replicate in IFN-deficient systems (Garcia-Sastre et al., 1998a; Garcia-Sastre et al., 1998b; Ludwig et al., 1999). IFN $\alpha / \beta$ are two important cytokines expressed in primary infected epithelia cells, that induce innate immunity. IFN $\alpha / \beta$-induction severely reduces viral replication even in the presence of NS1. Therefore recombinant viruses expressing 
altered NS1 with reduced capacity to suppress cellular IFN-induction could raise protective immunity and might represent interesting attenuated live vaccine candidates (Talon et al., 2000). Such viruses have been generated by reverse genetic techniques (s. 3.1.3) and have been successfully tested in experimental settings (Ferko et al., 2004).

\subsubsection{Plasmid-based reverse genetic techniques}

After initial experiments that implied the in vivo reconstitution of RNPs from plasmid-expressed RDRP, NP and vRNA (Pleschka et al., 1996) it became possible to generate recombinant influenza virus de novo totally from plasmid DNA (Fodor et al., 1999; Neumann et al., 1999), allowing complete genetic manipulation. This manipulation can either concern the combination/mixture of the genomic RNA-segments and/or the genesequences themselves. The technique involves the transfection of four plasmids expressing the viral RDRP and the NP together with eight plasmids (for all eight genomic RNAs) that generate a vRNA-like transcript. This again results in the in vivo reconstitution of active RNP-complexes, which will replicated and transcribe the vRNAs. Thereby all viral RNAs and proteins are generated and the viral replication cycle is established resulting in the production of infectious influenza viruses (for review: Garcia-Sastre, 1998; Neumann and Kawaoka, 1999; Palese et al., 1996).

Reverse genetics technique can be used to produce influenza vaccines based on recombinant virus (for detail see: Bardiya and Bae, 2005). These methods do not require selection procedures and eliminate the need for multiple passages in eggs, thereby reducing the time required for vaccine production. It is known that interference among the vaccine viruses of type$\mathrm{A}$ and $-\mathrm{B}$ can occur that affect the efficacy of the live attenuated vaccines by restricting their replication. To overcome that problem a chimeric virus (A/B) possessing chimeric (A/B) HA, and full-length B-type NA in the background of a type-A vaccine virus was created (Horimoto et al., 2004). This study provided a novel method for creating live attenuated vaccine from a single donor strain.

For different reasons the technique of reverse genetics has become highly relevant for anti-viral vaccine approaches. (I) For the production of regular IVs against wild type strains, that either grow poorly or are too pathogenic in eggs (s. later) one can generate strains carrying the HA and NA needed in the background of an egg adapted virus. This is normally done by reassortment of the wild type with the egg-adapted strain and can not be well controlled. This problem can be circumvented by plasmid based reverse genetics that allow the controlled design of the reassortant. (II) As mentioned the CAV are composed of HA- and NA-genes from the wild type 
strain and a mixture of the other six segments from wild type and donor virus. By choice of the according plasmids one can compose a CAV-strain that carries all six segments from the donor strain each with an adaptive mutation. This way it is less likely that a revertant virus will arise by mutation in one of the donor strain segments (s. 3.1.2) (Maassab and Bryant, 1999; Schickli et al., 2001). (III) It is possible to specifically design viruses with altered NS1-genes that could be used as highly attenuated life vaccines (s. 3.1.2), additionally modification of other viral genes (Murphy et al., 1997; Parkin et al., 1997) or of the replications efficiency of the genesegment (Muster et al., 1991) can be applied to further attanuate the virus. (IV) Viruses could be produced that lack an essential gene (e.g. NEP) (Watanabe et al., 2002b). The missing gene-product can be transcomplemented from an expression-plasmid in the transfected cell during virus generation. The recombinant viruses would be still infectious and lead to expression and presentation of viral proteins, but could not themselves establish a productive propagation as they are lacking the according gene.

Currently used IVs are prepared from egg-grown viruses (Wilschut and McElhaney, 2005). This method is not without limitations but has proven to be efficient. As mentioned earlyer (3.1.1), one particular problem that could arise would be production of a vaccine strain against an highly pathogenic avain influenza virus like the types that have recently infected humans. Besides bio-safety questions they pose further problems. The HA of these viruses is activated within the infected cell by ubiquitous proteases allowing the virus to spread through out the organism. Due to the special HAcharacteristics these viruses themselves are highly pathogenic birds and eggs as well as a vaccine strain that would carry the according HA. Therefore efficient virus production in embryonated eggs will be problematic (Lipatov et al., 2004). By plasmid based reverse genetic techniques recombinant viruses can be produced that have lost the pathogenic character of the HA and can replicate well in eggs (Chen et al., 2003; Li et al., 1999; Liu et al., 2003; Subbarao et al., 2003). This could additionally be combined with virus production in cell culture systems (s. p. 12) (Ozaki et al., 2004; Romanova et al., 2004) thereby overcoming the limitation posed by the number of embryonated eggs available at a given time (Stephenson et al., 2004).

It should also be mentioned that not only type-A influenza viruses but also type-B influenza viruses can be generated and manipulated by reverse genetic systems and can therefore also be engineered to fit the circulating wild type strains (Dauber et al., 2004; Hatta et al., 2004; Jackson et al., 2004; Maassab and Bryant, 1999). 


\subsection{Inhibitors of viral functions (Treatment and anti-viral chemoprophylaxis of influenza)}

\subsubsection{M2-Inhibitors}

Anti-viral treatment is generally considered a supporting measure to prevent and control outbreaks of epidemic influenza in addition to immunoprophylaxis. However, chemotherapy is the only option to combat the disease when there is no type-specific vaccine available as for instance upon the emergence of a pandemic shift variant. Two classes of substances are currently licensed in many countries for the treatment and/or prophylaxis of influenza, which includes the adamantane compounds amantadine and rimantadine, and the NA-inhibitors oseltamivir and zanamivir. Other small inhibitory compounds that target the viral polymerase complex are also introduced in this section, although none of them has been converted into a pharmaceutical product so far.

\subsubsection{M2-Inhibitors (Amantadine and Rimantadine)}

Amantadine (1-amino adamantane hydrochloride) and its derivative rimantadine ( $\alpha$-methyl-1-adamantane methylamine hydrochloride) have potent anti-viral activity against most influenza-A-viruses, because they block the viral M2 ion channel protein during the early stage of viral uncoating (Pinto et al., 1995). Specifically, the adamantane compounds inhibit the acidification of the virion inside the endosome, which prevents the intra-cellular release of the viral RNPs. The 50\% inhibitory concentration $\left(\mathrm{IC}_{50}\right)$ of most natural influenza-A-virus strains against adamantane compounds is in the range of 0.2 to $0.4 \mu \mathrm{g} / \mathrm{ml}$ as determined by plaque reduction assay (Appleyard et al., 1977; Hayden et al., 1980; Scholtissek and Faulkner, 1979). Amantadine and rimantadine have proven effectiveness in the treatment of uncomplicated influenza-A-virus infection. They can reduce the duration of fever and system symptoms by approximately one day when given within two days after onset of disease signs (Demicheli et al., 2000; Tominack and Hayden, 1987). Furthermore, both substances also have prophylactic effectiveness in reducing influenza-associated morbidity and clinical symptoms. A survey of studies undertaken with healthy adults demonstrated average effectiveness of $61 \%$ for amantadine and $72 \%$ for rimantadine in preventing laboratory confirmed influenza (Demicheli et al., 2000). During long-term prophylaxis amantadine was found to cause mild reversible adverse effects in a small proportion of the recipients, which involved central nervous system (CNS) and minor gastrointestinal 
complaints. No increase in side effects was observed during treatment with rimantadine compared to placebo (N.N., 1985).

An early recognized limitation for widespread clinical use of M2-blockers is the rapid emergence of drug-resistant viruses in tissue culture, in animal models and in patients (Appleyard et al., 1977; Hayden et al., 1989; Oxford et al., 1970). One study found that a total of $27 \%$ of children with laboratory-confirmed influenza shed resistant viruses after seven days of treatment with rimantadine (Hall et al., 1987). Unfortunately, such selected drug-resistant viruses are virulent, as they can transmit to family members and cause disease even when the contact persons were treated prophylactically with rimantadine (Hayden et al., 1989). Viruses that become insensitive to amantadine show complete cross-resistance to rimantadine and vice versa. Thus, the clinical usage of adamantane amine compounds has been limited by the reported adverse effects, the induction of viral drug resistance and the inactivity towards influenza-B-viruses. Nevertheless, these drugs are still recommended as a cost-effective choice particularly in influenza chemoprophylaxis (Harper et al., 2004). It is noteworthy, that amantadine resistance has also been detected in the highlypathogenic H5N1 viruses currently circulating in South East Asia (Puthavathana et al., 2005). Thus, adamantane compounds are not an option to treat such infections.

\section{Clinical use for treatment and prophylaxis}

Amantadine and rimantadine are approved for treatment of adults and children older than 12 years at two daily $100 \mathrm{mg}$ doses. The substances should carefully be used in individuals above 64 years in age and patients with impaired renal functions and halving of the daily doses is recommended. Only amantadine is licensed for treatment of children between 1 and 9 years and should be dosed with $5 \mathrm{mg} / \mathrm{kg}$ per day. In order to avoid emergence and transmission of drug-resistent viruses, treatment should be kept to a minimal time of 3 to 5 days until disease symptoms disappear. Chemoprophylaxis can be considered for protection among high-risk groups including children and adults with chronic pulmonary or cardiac disease, immunocompromised persons with a reduced response to vaccines or in the case of a poor match between an epidemic virus strain and the current vaccine. Since the adamantane compounds do not interfere with the development of neutralizing antibodies (Tominack and Hayden, 1987), they can also be used for the protection of persons at high risk to bridge the time gap between vaccination and the establishment of an efficient immune status. For adults and children older than 9 years two $100 \mathrm{mg}$ doses of amantadine or rimantadine per day are recommended. Children between 
1 and 9 years should receive a maximum of $150 \mathrm{mg}$ per day in two divided doses.

\subsubsection{Neuraminidase (NA)-inhibitors}

Two anti-viral drugs that inhibit both influenza-A and B-viruses, zanamivir (Relenza ${ }^{\mathrm{TM}}$, GlaxoSmithCline) and oseltamivir (Tamiflu ${ }^{\mathrm{TM}}$, Roche Pharmaceuticals) have recently been approved for general use in the USA, Australia, Europe and Japan. The current knowledge suggests that NAinhibitors (NI) will have a better clinical utility than the M2-blockers, because these substances are broadly effective against type-A and -B influenza viruses including highly virulent avian virus strains. Further, they appear to have a very low frequency of adverse effects and are less prone to induce drug resistance. Zanamivir and oseltamivir function as slow binding, substrate competitive inhibitors that strongly reduce viral NA-activity by interacting with five sub-sites close to the enzymatic pocket of the NA. The $\mathrm{IC}_{50}$ values of these inhibitors were found to be in the range of $0.8-8.8 \mathrm{nM}$ depending on the virus types and subtypes (McKimm-Breschkin et al., 2003).

Targeting of the viral NA does not require the delivery of an inhibitor into the cell interior, because the enzyme is a surface glycoprotein. Influenza viruses attach to the host cell through binding of the viral HA to sialic acid moieties that are conjugated to cellular glycoproteins. By the time of progeny virus budding these receptor determinants need to be removed to allow efficient release from the host cell. This is accomplished by the viral NA (acylneuraminyl hydrolase, EC 3.2.1.18) that hydrolyzes glycosidic linkages adjacent to N-acetyl-neuraminic acid (Neu5Ac, sialic acid). Thus, blockade of NA-activity by antibodies, temperature-sensitive mutation or inhibitory substances results in the aggregation of budding virions at the cell membrane and, hence, reduction of virus release (Compans et al., 1969; Palese and Compans, 1976; Palese et al., 1974). In infected animals or humans, NA probably also enhances penetration of the virion through the viscous mucus on respiratory epithelia, which contains sialic acids (Matrosovich et al., 2004). Thus, inhibition of viral NA-activity was the rationale behind several efforts to identify substances that would reduce influenza virus spread and replication.

The development of the current NIs was based on early characterizations of the sialic acid transition state analogue 2-deoxy-2,3 dehydro Nacetylneuraminc acid (Neu 5Ac2en) (Meindl et al., 1974) and the determination of the three-dimensional structure of the NA by X-ray crystallography (Colman et al., 1983; Varghese et al., 1983; Varghese et al., 1992). Neu 5Ac2en had been shown to inhibit viral NA-acitvity but was not 
protective in a mouse model of influenza (Palese and Schulman, 1977). Based upon computer-assisted drug design, von Itzstein et al. demonstrated that the introduction of positively charged amino- or guanidino moieties at position 4 of Neu 5Ac2en increased NA inhibition by two to four orders of magnitude (von Itzstein et al., 1993). Importantly, the inhibition of NAactivity by 4 guanidino-Neu5Ac2en that is now also termed zanamivir translated into efficient reduction of viral replication of type-A and Binfluenza viruses in the nanomolar range in vitro and dose-dependent decrease of viral titers in infected animals (von Itzstein et al., 1993; Woods et al., 1993). Zanamivir has low oral bioavailability, but shows high antiviral activity in humans or animals when administered topically by inhalation of dry-powder aerosol (Cass et al., 1999). The second currently approved NA inhibitor compound oseltamivir (3R,4R,5S-4acetamido5-amino-3-(1-ethylpropoxyl)-1-cyclohexene-1carboxylic acid, also termed GS4071/Ro64-0802) has similarly potent activities against type A and B influenza viruses (Kim et al., 1998). Oseltamivir emerged from an independent NA structure-based study and is based on a cyclohexen ring structure in which the polar glycerol side chain of the sialic acid analogues is replaced by a lipophilic 3-pentyloxy moiety (Kim et al., 1997). Importantly, oseltamivir has high oral anti-viral activity when administered as its methylester pro-drug, GS4071/oseltamivir phosphate, that is converted to the active drug by hepatic enzymes (Hayden et al., 1999b; Li et al., 1998; Mendel et al., 1998).

\section{Effectiveness}

Zanamivir and oseltamivir have potent anti-viral effectiveness against community-acquired influenza and are in general safe to use in healthy adults (Abramson, 1999; Boivin et al., 2000; Hayden et al., 1997; Makela et al., 2000; Monto et al., 1999; N.N., 1985). In clinical trials the NIs significantly shortened disease duration and reduced symptoms and viral loads when treatment was initiated within 26 hours post infection (Hayden et al., 1996; Hayden et al., 1999b). Even, when inhalation of zanamivir was begun within 30 hours after onset of symptoms the time to alleviation of major disease signs (cough, myalgias, fever, headache) was shortened by one to two days and patients were able to resume normal activities earlier (Hayden et al., 1997; Monto et al., 1999). Initiation of therapy later than 30 hours after disease onset still reduced viral loads but was less beneficial for symptom recovery. Two $75 \mathrm{mg}$ daily doses of oseltamivir for five days were shown to reduce shedding of virus and the severity and duration of influenza symptoms by one to two days when therapy was begun within 36 hours after onset of disease signs (Nicholson et al., 2000; Treanor et al., 2000). Some side effects that included diarrhea, nausea and nasal symptoms were 
observed during clinical testings of zanamivir but were similar in placebo groups (GlaxoWellcome, 2001). The NI substances are also highly effective to prevent spread of the disease. A post-exposure protection study with zanamivir demonstrated $79 \%$ efficacy in preventing transmission of influenza to family members, when the index case was treated with zanamivir (Hayden et al., 2000). Oseltamivir had a comparably high efficacy in preventing laboratory-confirmed influenza by $74 \%$ and influenza with fever by $82 \%$ (Hayden et al., 1999a). Within households, one $75 \mathrm{mg}$ dose oseltamivir per day was $89 \%$ protective against clinical influenza even when the index cases were not treated (Welliver et al., 2001). Thus, to prevent the spread of the flu within household contacts the NIs appear to be preferable compared to the M2-blockers that can induce the emergence and transmission of virulent drug-resistant viruses.

\section{Resistance to NA-inhibitors}

During the development of NIs for clinical use it was recognized that viruses with a reduced drug sensitivity could be selected in tissue culture (summarized in (McKimm-Breschkin, 2000; Tisdale, 2000)). Resistance can be characterized by various methods including $\mathrm{IC}_{50}$-determination of the viral NA, by plaque reduction assays (number and size) and yield reduction assay in tissue culture (Matrosovich et al., 2003; Tisdale, 2000). Under laboratory conditions several passages are usually required to select such variants, which is different to amantadine-resistant viruses that can emerge in a single cycle experiment. Drug-resistant viruses were also isolated from diseased persons treated with NIs (Gubareva et al., 2001; Gubareva et al., 1998; Kiso et al., 2004; Zambon and Hayden, 2001). However, the available data on the pathogenicity of these mutant viruses in animal models suggest that they have reduced replication capability in vivo and may therefore be clinically less relevant in humans.

Resistance to NIs was found to be complex, because it can be associated with mutations in the NA, the HA or synergistically in both genes. NAmutations that confer reduced drug sensitivity were identified at amino acid residues 119, 152, 274, 292 and 294 (based on N2-NA numbering) (Gubareva, 2004; Zambon and Hayden, 2001). These amino acids are part of or cluster around the conserved catalytic pocket and their mutation can decrease the enzymatic activity to below $5 \%$ and some also destabilize the enzyme (Varghese et al., 1998). The various NI-molecules slightly differ in their interactions with the enzyme. Thus, a given NA-mutant enzyme may show a range of sensitivity against different inhibitors (Gubareva et al., 2001). Interestingly, some viruses with a reduced sensitivity to NIs were found to carry mutations in the HA, which affected the receptor binding site in the globular head region, the stalk region and the $\mathrm{HA}_{2}$-subunit (McKimm- 
Breschkin, 2000). Apparently, the HA-mutations reduce drug sensitivity by decreasing the affinity for cellular sialic acid receptor molecules and thereby easing the release of budding viruses from the plasma membrane. These findings corroborate the concept that efficient viral replication requires a carefully balanced interplay between the strength of $\mathrm{HA} /$ receptor binding and the activity of the NA that removes these receptor determinants (Wagner et al., 2000).

\section{Clinical use for treatment and chemoprophylaxis}

The use of zanamivir (Relenza ${ }^{\mathrm{TM}}$ ) and oseltamivir (Tamiflu ${ }^{\mathrm{TM}}$ ) is recommended for the treatment of uncomplicated influenza caused by typeA and B-viruses (Harper et al., 2004). Therapy with either drug should be initiated within 48 hours after the onset of disease signs and should be continued for five days (GlaxoWellcome, 2001; Roche, 2001). It is important to consider that bacterial superinfections may occur that would not be affected by these anti-virals. Neither substance has been shown to prevent serious complications of influenza like pneumonia. Zanamivir is approved for treatment of influenza in persons aged 7 years and older. The recommended dosage is two inhalations of $5 \mathrm{mg}$ doses twice a day using the inhalation device provided by the manufacturer. Zanamivir is not recommended for persons with underlying respiratory conditions like asthma or chronic obstructive pulmonary disease, because of the risk of precipitating bronchospasm in such patients (GlaxoWellcome, 2001). Oseltamivir can be used for treatment of patients of 1 year or older. Depending on the age, the recommended doses for children above 12 years and adults are two $75 \mathrm{mg}$ capsules a day. Two daily doses of $15-30 \mathrm{mg}$ is recommended for children under $15 \mathrm{~kg}, 2 \times 45 \mathrm{mg}$ for children between $15-23 \mathrm{~kg}$ and $2 \times 60 \mathrm{mg}$ for persons weighing $>23-40 \mathrm{~kg}$. Currently, Tamiflu ${ }^{\mathrm{TM}}$ but not Relenza ${ }^{\mathrm{TM}}$ is licensed for chemoprophylaxis in children older than 12 years and in adults. For persons with creatinine clearance of $10-30 \mathrm{ml} / \mathrm{min}$, halving of the usual dosage for therapy or prophylaxis is recommended. Two approaches are possible, a seasonal prophylaxis that provides a $92 \%$ reduction of confirmed influenza infection in a vaccinated population of frail elderly persons (McClellan and Perry, 2001), and a short-term prophylaxis for controlling institutional outbreaks by breaking the virus circulation.

Several further compounds that inhibit the influenza virus NA were identified in independent efforts and have been evaluated as anti-influenza agents. Thus, the cyclopentane derivatives BCX-1812 (RWJ-270201), BCX1827, BCX-1898 and BCX-1923 (from BioCryst Pharmaceuticals) as well as the pyrrolidine-based A315675 (from Abbott Laboratories) showed strong potent anti-viral activies at least in vitro (Kati et al., 2002; Smee et al., 
2001). Thus, although development of BCX-1812 has been halted after showing a lack of activity in a phase III clinical trial (Chand et al., 2005), additional NIs may emerge as anti-influenza drugs in the future.

\subsubsection{RDRP- and endonuclease-inhibitors}

Two unique properties of the trimeric RNA-dependent RNA-polymerase of influenza viruses, which are not shared by cellular enzymes, provide attractive opportunities for anti-viral interference with possibly little disturbances of the host cell. First, the polymerase exhibits an endonuclease activity that cleaves the first $10-13$ nucleotides including the 5'-cap structure from nascent host RNA-polymerase II cap transcripts and use them to prime viral mRNAs (Lamb and Krug, 2001). Second, the viral polymerase replicates the negative-sense viral RNA-segments via unprimed synthesis of a complementary positive-strand RNA-intermediate. For both of these activities, inhibitory small molecule compounds have been identified, some of which were also shown to reduce viral propagation in tissue culture and/or in infected mice. However, further clinical development has not been reported for any of those substances so far.

The viral endonuclease activity is associated with the PB1-subunit and depends on binding of the polymerase to the terminal ends of the vRNAtemplate and the cap structures of nascent mRNA-transcripts ( $\mathrm{Li}$ et al., 2001). The endonuclease most likely utilizes a two metal ion mechanism for cleavage of the cellular nucleic acid (Klumpp, 2004a). It has been shown that derivatives of the fungal metabolite flutimide as well as a class of 4substituted 2,4-dioxobutanoic acids specifically inhibited the cap-dependent endonuclease, presumably by interaction with the active catalytic site of the enzyme (Hastings et al., 1996; Parkes et al., 2003; Tomassini et al., 1994; Tomassini, 1996). The most potent compounds of these two classes had $\mathrm{IC}_{50}$ values in the range of $0.2-6 \mu \mathrm{M}$ when tested in virus yield assays in tissue culture experiments. Further, intranasal instillation of the L-735,882 compound was reported to inhibit viral titers in nasal washes of mice infected with influenza virus A/PR/8/34 virus, but the effects on disease progression were not studied (Hastings et al., 1996).

Another screening effort has identified T-705 (6-fluoro-3-hydroxy-2pyrazinecarboxamide) to have potent and selective anti-influenza activity. T-705 showed $\mathrm{IC}_{50}$ values of less than $0.5 \mu \mathrm{g} / \mathrm{ml}$ in virus yield assays in MDCK cells against all three influenza virus types (A, B, C) with no signs of cytotoxicity (Furuta et al., 2002). Importantly, T-705 was also orally active in a mouse model and shown to significantly reduce viral lung titers and enhance survival rates from $20 \%$ to $100 \%$ after infection with influenza virus $\mathrm{A} / \mathrm{PR} / 8 / 34$ virus at a dose of $200 \mathrm{mg} / \mathrm{kg}$ per day (Furuta et al., 2002; 
Takahashi et al., 2003). Although the basis for its anti-viral activity was unclear at that time, T-705 was found to inhibit replication of an oseltamivirresistant mutant virus in vitro suggesting that this inhibitor targets a different viral function (Takahashi et al., 2003). Indeed, recent analyses showed that the compound is metabolized inside the cell into T-705-ribofuranosyl-5'triphosphate (T-705-RTP), which is a potent and selective inhibitor of ApGprimed viral RNA-polymerase activity (Furuta et al., 2005). These findings show that T-705 may have the potential to become a novel oral antiinfluenza drug that targets a viral function not blocked by one of the currently licensed NIs or M2-blockers.

\section{TARGETING HOST CELL FUNCTIONS AND FACTORS}

\subsection{Inhibitors of cell signaling and apoptosis}

Influenza viruses only have a limited coding capacity. Thus, these viruses employ functions of their host-cell for efficient replication. These dependencies create opportunities to design novel anti-viral strategies by targeting specific host cell functions.

Cell fate decisions in response to extra-cellular agents, including pathogenic invaders are commonly mediated by intra-cellular signaling cascades that transduce signals into stimulus specific actions, e.g. changes in gene expression patterns, alterations in the metabolic state of the cell or induction of programmed cell death (apoptosis). Thus, these signaling molecules are at the bottleneck of the control of cellular responses. In this section we will review the recent advances in the analysis of influenza virus induced signaling pathways and first attempts to use signaling mediators as targets for anti-viral approaches.

\subsubsection{Intra-cellular signaling cascades - MAP-kinases and the IKK/NFKB-module}

Mitogen activated protein kinase (MAPK)-cascades have gained much attention as being critical transducers to convert a variety of extra-cellular signals into a multitude of responses (English et al., 1999; Hazzalin and Mahadevan, 2002; Widmann et al., 1999) Thereby, these pathways regulate numerous cellular decision processes, such as proliferation and 
differentiation, but also cell activation and immune responses (Dong et al., 2002). Four different members of the MAPK-family that are organized in separate cascades have been identified so far: ERK (extra-cellular signal regulated kinase), JNK (Jun-N-terminal kinase), p38 and ERK5/BMK-1 (Big MAP kinase) (Garrington and Johnson, 1999; Widmann et al., 1999). These MAPKs are activated by a dual phosphorylation event on threonine and tyrosine mediated by MAPK-kinases (MAPKK also termed MEKs or MKKs). The MAPK "ERK" is activated by the dual-specific MAPKK MEK1 and -2 that are controlled by the upstream serine threonine MAPKKkinase Raf. Raf, MEK and ERK form the prototype module of a MAPK-pathway and are also known as the classical mitogenic cascade. The MAPK p38 and JNK are activated by MKK3/6 and MKK4/7, respectively, and are predominantly activated by pro-inflammatory cytokines and certain environmental stress conditions. The MEK5/ERK5 module is both activated by mitogens and certain stress inducers. There is evidence that all these different MAPK-cascades are activated upon infection with RNA-viruses, including influenza viruses. Thus, these signaling cascades may serve different functions in viral replication and host cell response.

Another important signaling pathway, which is commonly activated upon virus infection is the IKB-kinase (IKK)/NFKB-signaling module (Hiscott et al., 2001). The $\mathrm{NF \kappa B} / \mathrm{I} \kappa \mathrm{B}$ family of transcription factors promote the expression of well over 150 different genes, such as cytokine or chemokine genes, or genes encoding for adhesion molecules or anti- and pro-apoptotic protein (Pahl, 1999). The canonical mechanism of NFKB activation includes

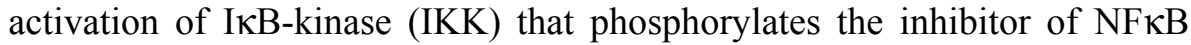
(IKB) and targets the protein for subsequent degradation (Delhase and Karin, 1999; Karin, 1999b). This leads to the release and migration of the transcriptionally active NFKB factors to the nucleus (Ghosh, 1999; Karin and Ben-Neriah, 2000). The IKK-complex consists of at least three isozymes of IKK: (I) IKK1/IKK $\alpha$, (II) IKK2/IKK $\beta$ and (III) NEMO/IKK $\gamma$. The most important isozyme for NFKB-activation via the degradation of IKB is IKK2 (Karin, 1999a). NEMO acts as a scaffolding protein for the large IKK complex (Courtois et al., 2001) that contains still other kinases such as MEKK1 (MAPKK-kinase 1) (Lee et al., 1998), NIK (NFKB inducing kinase) (Nemoto et al., 1998; Woronicz et al., 1997) and the dsRNAactivated protein-kinase (PKR) (Gil et al., 2000; Zamanian-Daryoush et al., 2000).

Both NFKB and the JNK MAPK-pathway regulate one of the most important anti-viral gene expression events, the transcriptional induction of interferon beta (IFN $\beta$ ) (Maniatis et al., 1998). IFN $\beta$ is one of the first antiviral cytokines to be expressed upon virus infection, initiating an autoamplification loop to cause an efficient and strong type-I IFN response. The IFN $\beta$ enhanceosome, which mediates the inducible expression of IFN $\beta$, 
carries binding sites for transcription factors of three families, namely the AP-1 family members and JNK targets c-Jun and ATF-2, the NFKB factors p50 and p65, and the interferon-regulatory factors (IRFs) (Hiscott et al., 1999; Thanos and Maniatis, 1995). In the initial phase of a virus infection this promoter element specifically binds the constitutively expressed and specifically activated IRF3-dimer (Taniguchi and Takaoka, 2002). AP-1and NFKB-transcription factors are activated by a variety of stimuli. However, a strong IRF3-activation is selectively induced upon infection with several RNA-viruses, in particular by the dsRNA, which accumulates during replication (Lin et al., 1998; Yoneyama et al., 1998). Thus, IRF3 is the major determinant of a strong virus- and dsRNA-induced IFN $\beta$-response.

\subsubsection{MAP Kinase-cascades and influenza virus-infection: The ERK-pathway}

Interestingly all four so far defined MAPK-family members are activated upon an influenza virus infection (Kujime et al., 2000; Ludwig et al., 2001; Pleschka et al., 2001; Virginia Korte and S.L., unpublished) and recent work has helped to get a clearer picture of the importance of the ERK-signaling pathway for influenza virus replication.

The activation of the MAP-kinase ERK upon productive influenza virus infection (Kujime et al., 2000) appears to serve a mechanism that is beneficial for the virus (Pleschka et al., 2001). Strikingly, blockade of the pathway by specific inhibitors of the upstream kinase MEK and dominantnegative mutants of ERK or the MEK-activator Raf resulted in a strongly impaired growth of both, influenza A- and B-type viruses (Pleschka et al., 2001). Conversely, virus titers are enhanced in cells expressing active mutants of Raf or MEK (Ludwig et al., 2004; Olschlager et al., 2004). This has not only been demonstrated in cell culture but also in vivo in infected mice expressing a constitutively active form of the Raf-kinase in the alveolar epithelial cells of the lung (Olschlager et al., 2004). While in the wt-situation influenza viruses primarily infect bronchiolar epithelial cells, there is efficient replication in the alveolar layer most exclusively in the cells carrying the transgene. As a consequence this results in an earlier death of the transgenic animals (Olschlager et al., 2004). This indicates that activation of the Raf/MEK/ERK pathway is required for efficient virus growth. Noticeably, inhibition of the pathway did not significantly affect viral RNA- or protein-synthesis (Pleschka et al., 2001). The pathway rather appears to control the active nuclear export of the viral RNP-complexes that are readily retained in the nucleus upon blockade of the signaling pathway. Most likely this is due to an impaired activity of the viral nuclear export protein NEP (Pleschka et al., 2001). This indicates that active RNP-export is an induced rather than a constitutive event, a hypothesis supported by a late 
activation of ERK in the viral life cycle. So far the detailed mechanism of how ERK regulates export of the RNPs is unsolved. There are two likely scenarios: Either it does occur directly via phosphorylation of a viral protein involved in RNP-transport or by control of a cellular export factor. Although in the initial studies no alteration of the overall phosphorlyation status of the NP, M and NEP proteins was observed (Pleschka et al., 2001) there are now first indications that certain phosphorylation sites of the NP indeed are affected by MEK-inhibition (S.P., unpublished data). It remains to be shown, whether this is of functional relevance for the RNP-export process. It is striking that MEK-inhibitors are not toxic for the cell, while more general blockers of the active transport machinery, such as leptomycin-B exert a high toxicity even in quite low concentrations. This may indicate that MEKinhibitors are no general export blockers but only block a distinct nuclear export pathway. Indeed there are first evidences that the classical mitogenic cascade specifically regulates nuclear export of certain cellular RNA-protein complexes. In LPS-treated mouse macrophages MEK-inhibition results in a specific retention of the TNF-mRNA in the nucleus (Dumitru et al., 2000). This is also observed in cells deficient for Tpl-2, an activator of MEK and ERK. In these cells the failure to activate MEK and ERK by LPS again correlated with TNF mRNA retention while other cytokines are normally expressed (Dumitru et al., 2000). Thus the ERK-pathway may regulate a specific cellular export process but leaves other export mechanisms unaffected. It is likely that such a specific export pathway is employed by influenza-A and B-viruses.

The finding of an anti-viral action of MEK-inhibitors prompted further research showing that replication of other viruses, such as Borna disease virus (Planz et al., 2001), Visna virus (Barber et al., 2002) or Coxsackie $\mathrm{B} 3$ virus (Luo et al., 2002) is also impaired upon MEK-inhibition.

Requirement of Raf/MEK/ERK-activation for efficient influenza virus replication may suggest that this pathway may be a cellular target for antiviral approaches. Besides the anti-viral action against both, A- and B-type viruses (Ludwig et al., 2004), MEK-inhibitors meet two further criteria which are a prerequisite for a potential clinical use. Although targeting an important signaling pathway in the cell the inhibitors showed a surprisingly little toxicity (a) in cell culture (Ludwig et al., 2004; Planz et al., 2001; Pleschka et al., 2001) (b) in an in vivo mouse model (Sebolt-Leopold et al., 1999) and (c) in clinical trials for the use as anti-cancer agent (Cohen, 2002). In the light of these findings it was hypothesized that the mitogenic pathway may only be of major importance during early development of an organism and may be dispensable in adult tissues (Cohen, 2002). Another very important feature of MEK-inhibitors is that they showed no tendency to induce formation of resistant virus variants (Ludwig et al., 2004). Although targeting of a cellular factor may still raise the concern about side effects of a drug, it appears likely that local administration of an agent such as a MEK- 
inhibitor to the primary site of influenza virus infection, the lung, is well tolerated. Here the drug primarily affects differentiated lung epithelial cells for which a proliferative signaling cascade like the Raf/MEK/ERK-cascade may be dispensable. Following this approach it was recently demonstrated that the MEK inhibitor U0126 is effective in reducing virus titers in the lung of infected mice after local administration (O.P., S.P. and S.L., unpublished).

\subsubsection{Protein kinase C: A viral entry regulator}

Activation of the classical mitogenic Raf/MEK/ERK-cascade is initiated by yet other phosphorylation events. The kinase Raf is known to be regulated by phosphorylation of different upstream kinases including members of the protein kinase C (PKC)-family (Cai et al., 1997; Kolch et al., 1993).

The PKC-superfamily consists of at least 12 different PKC-isoforms that carry out diverse regulatory roles in cellular processes by linking into several downstream signaling pathways (Toker, 1998). Beside a regulation of the Raf/MEK/ERK-cascade and other downstream pathways, PKCs may have additional functions during viral replication. A role of PKCs in the process of entry of several enveloped viruses has been proposed based on the action of protein kinase inhibitors $\mathrm{H} 7$ and staurosporine (Constantinescu et al., 1991) as well as by the calcium-channel blocker verapamil (Nugent and Shanley, 1984). Influenza virus infection or treatment of cells with purified viral HA results in rapid activation of PKCs upon binding to host-cell surface receptors (Arora and Gasse, 1998; Kunzelmann et al., 2000; Rott et al., 1995). In a recent study it was shown that the pan PKC-inhibitor bisindolylmaleimide-I prevented influenza virus entry and subsequent infection in a dose dependent and reversible manner (Root et al., 2000). Using a dominant-negative mutant approach this function was assigned to the PKCßII-isoform. Overexpression of a phosphorylation-deficient mutant of PKCBII revealed that the kinase is a regulator of late endosomal sorting. Accordingly, expression of the PKCBII-mutant resulted in a block of virus entry at the level of late endosomes (Sieczkarski et al., 2003; Sieczkarski and Whittaker, 2002). Thus, a specific inhibition of PKCBII may be a suitable approach to blunt virus replication at a very early time point in the replication cycle.

\subsubsection{Influenza virus and the IKK/NFKB-pathway}

Activation of the transcription factor NFKB is a hallmark of most infections by viral pathogens (Hiscott et al., 2001) including influenza 
viruses (reviewed in: Julkunen et al., 2000; Ludwig et al., 2003; Ludwig et al., 1999). Influenza viral NFKB-induction involves activation of IкBkinase (IKK) (Wurzer et al., 2004) and is also achieved with isolated influenza virus components. This includes dsRNA (Chu et al., 1999) or over-expression of the viral HA, NP or M1 proteins (Flory et al., 2000). Since gene expression of many pro-inflammatory or anti-viral cytokines, such as IFN $\beta$ or TNF $\alpha$, is controlled by NFKB the concept emerged that IKK and $\mathrm{NF} \kappa \mathrm{B}$ are essential components in the innate immune response to virus infections (Chu et al., 1999). Accordingly, influenza virus-induced IFN $\beta$ promoter activity is impaired in cells expressing transdominant negative mutants of IKK2 or IKB $\alpha$ (Wang et al., 2000; Wurzer et al., 2004).

Nevertheless, IKK and NFKB might not only have anti-viral functions as two recent studies demonstrate that influenza viruses replicate much better in cells where NFKB is pre-activated (Nimmerjahn et al., 2004; Wurzer et al., 2004). Conversely, influenza virus titers from different host cells in which $\mathrm{NF} \kappa \mathrm{B}$-signaling was impaired by means of specific inhibitors or dominantnegative mutants, a dramatic reduction could be observed (Nimmerjahn et al., 2004; Wurzer et al., 2004). Thus, in the context of an influenza virus infection a function of NFKB to support virus replication appears to be dominant over the function as a transcription factor in the anti-viral response. On a molecular basis this was shown to be due to the NFKBdependent expression of pro-apoptotic factors, such as TNF-related apoptosis inducing ligand (TRAIL) or FasL (Wurzer et al., 2004). Inhibition of virus induced expression of these factors results in strongly impaired viral growth. This links the pro-viral action of NF $\kappa B$ to the induction of apoptosis, a process that will be discussed in the next section. Finally, viral need for NFKB-activity suggests that this pathway may be suitable as a target for anti-viral intervention. To this end we have shown recently that several pharmacological inhibitors of $\mathrm{NF \kappa B}$ act anti-viral in vivo, without toxic side effects or the tendency to induce resistant virus variants (I. Mazur, W. Wurzer, C. Erhardt, T. Silberzahn, T.W., O.P., S.P. and S.L, unpublished).

\subsubsection{Influenza virus-induced programmed cell death (Apoptosis)}

Another cellular signaling response commonly observed upon virus infections, including influenza virus is the induction of the apoptotic cascade. Apoptosis is a morphological and biochemical defined form of cell death (Kerr et al., 1972) and has been demonstrated to play a role in a variety of diseases, including virus infections (Razvi and Welsh, 1995). Apoptosis is mainly regarded to be a host cell defense against virus 
infections since many viruses express anti-apoptotic proteins to prevent this cellular response. The central component of the apoptotic machinery is a proteolytic system consisting of a family of cysteinyl proteases, termed caspases (for review see: Cohen, 1997; Thornberry and Lazebnik, 1998). Two groups of caspases can be distinguished: upstream initiator caspases such as caspase- 8 or caspase- 9 , which cleave and activate other caspases and downstream effector caspases, including caspase- $3,-6$ and -7 , that cleave a variety of cellular substrates, thereby disassembling cellular structures or inactivating enzymes (Thornberry and Lazebnik, 1998). Caspase-3 is the most intensively studied effector caspase. Work on caspase-3 deficient MCF-7 breast carcinoma cells has revealed a caspase-3 driven feedback loop, that is crucial to mediate the apoptotic process (Janicke et al., 1998; Slee et al., 1999). Thus, caspase-3 is a central player in apoptosis regulation and the level of pro-caspase- 3 in the cell determines the impact of a given apoptotic stimulus.

It is long known that influenza virus infection with A- and B-type viruses results in the induction of apoptosis both in permissive and un-permissive cultured cells as well as in vivo (Fesq et al., 1994; Hinshaw et al., 1994; Ito et al., 2002; Mori et al., 1995; Takizawa et al., 1993). Interestingly, viral activation of MAPKs or upstream kinases has been linked to the onset of apoptosis. In a mouse model for a neurovirulent influenza infection, JNKactivity correlated with apoptosis induction in the infected brain (Mori et al., 2003). In embryonic fibroblasts deficient for the MAPKK-kinase ASK-1 the virus-induced JNK-activation was blunted concomitant with an inhibition of caspase-3 activation and virus-induced apoptosis (Maruoka et al., 2003). As an extrinsic mechanism of viral apoptosis induction it has been noted quite early on that the Fas receptor/FasL-apoptosis inducing system (Fujimoto et al., 1998; Takizawa et al., 1995; Takizawa et al., 1993; Wada et al., 1995) is expressed in a PKR-dependent manner in infected cells (Takizawa et al., 1996). This most likely contributes to virus-induced cell death via a receptor mediated FADD/caspase-8-dependent pathway (Balachandran et al., 2000). Another mode of viral apoptosis induction might occur via activation of TGF- $\beta$ that is converted from its latent form by the viral NA (Schultz-Cherry and Hinshaw, 1996). Within the influenza virus infected cell the apoptotic program is mediated by activation of caspases (Lin et al., 2002; Takizawa et al., 1999; Zhirnov et al., 1999) with a most crucial role of caspase-3 (Wurzer et al., 2003).

Although it is now well established that influenza virus infection induces caspses and subsequent apoptosis, the consequence for virus replication or host cell defense is still under a heavy debate (reviewed in (Lowy, 2003; Ludwig et al., 1999; Schultz-Cherry et al., 1998).

With the identification of PB1-F2, a new influenza virus protein expressed from $\mathrm{a}+1$ reading frame of the PB1 polymerase gene segment, a pro-apoptotic influenza virus protein has been discovered (Chen et al., 
2001). PB1-F2 induces apoptosis via the mitochondrial pathway if added to cells and infection with recombinant viruses lacking the protein results in reduced apoptotic rates of lymphocytes (Chen et al., 2001). However, most of the avian virus strains are lacking the PB1-F2 reading frame and PB1-F2deficient viruses do not affect apoptosis in a variety of other host cells (Chen et al., 2001). These results have let to the assumption that apoptosis induction by PB1-F2 may be required for the specific depletion of lymphocytes during an influenza virus infection, a process which is observed in infected animals (Tumpey et al., 2000; Van Campen et al., 1989a; Van Campen et al., 1989b).

A recent study adds a new aspect to the open discussion by the surprising observation that influenza virus propagation was strongly impaired in the presence of caspase inhibitors (Wurzer et al., 2003). This dependency on caspase activity was most obvious in cells where caspase-3 was partially knocked-down by siRNA (Wurzer et al., 2003). Consistent with these findings, poor replication efficiencies of influenza-A-viruses in cells deficient for caspase-3 could be boosted 30-fold by ectopic expression of the protein. Mechanistically, the block in virus propagation appeared to be due to the retention of viral RNP-complexes in the nucleus preventing formation of progeny virus particles (Wurzer et al., 2003). Interestingly the findings are consistent with a much earlier report showing that upon infection of cells over expressing the anti-apoptotic protein Bcl-2 the viral RNP-complexes were retained in the nucleus (Hinshaw et al., 1994) resulting in repressed virus titers (Olsen et al., 1996). Furthermore the recently identified proapoptotic PB1-F2 (Chen et al., 2001) is only expressed in later phases of replication consistent with a later step in the virus life cycle that requires caspase activity (Wurzer et al., 2003). The observation of a caspase requirement for RNP-nuclear export was quite puzzling since this export process was shown before to be mediated by the active cellular export machinery involving the viral nuclear export protein (NS2/NEP) (Neumann et al., 2000; O'Neill et al., 1998) and the anti-apoptotic Raf/MEK/ERKcascade (Pleschka et al., 2001). Caspase activation does not support, but rather inhibit the active nuclear export machinery by cleavage of transport proteins. This suggests an alternate strategy by which caspases may regulate RNP-export, e.g. by directly or indirectly increase the diffusion limit of nuclear pores (Faleiro and Lazebnik, 2000) to allow passive diffusion of larger proteins. Such a scenario is supported by the finding that isolated NPs or RNP-complexes, which are nuclear if ectopically expressed, can partially translocate to the cytoplasm upon stimulation with an apoptosis inducer in a caspase-3-dependent manner (Wurzer et al., 2003). These findings can be merged into a model in which the RNPs are transported via an active export mechanism in intermediate steps of the virus life cycle. Once caspase activity increases in the cells, proteins of the transport machinery get destroyed, however, widening of nuclear pores may allow the viral RNPs to 
use a second mode of exit from the nucleus (Faleiro and Lazebnik, 2000). That would be a likely mechanism to further enhance RNP-migration to the cytoplasm in late phase of the viral life cycle and thereby support virus replication. Such a complementary use of both "active" (Raf/MEK/ERKdependent) and "passive" (caspase-dependent) transport mechanisms is supported by the observation, that at concentrations of MEK- and caspaseinhibitors, which only poorly block influenza virus replication alone, efficiently impaired virus propagation if used in combination (Wurzer et al., 2003). Thus, while both pathways do not interfere with each other (Wurzer et al., 2003) they appear to synergize to mediate RNP-export via different routes.

Therefore one may conclude that influenza virus has acquired the capability to take advantage of supposedly anti-viral host cell responses to support viral propagation. This includes early induction of caspase activity but not necessarily execution of the full apoptotic process that most likely is an anti-viral response. This dual role of "early" versus "late" apoptotic events during virus replication may exclude the use of caspase-inhibitors as anti-flu agents, although in cell culture these inhibitors may have a beneficial outcome for the host cell.

\subsubsection{Other cellular targets: Glyocosidases and proteases}

Besides mediators of signaling and apoptosis a variety of other cellular enzymes are required for efficient virus growth. There are also some initial attempts to use these components as target for an anti-viral intervention.

The viral glycoproteins are glycosylated in the endoplasmic reticulum (ER) and the ER- $\alpha$-glycosidase-I is responsible for the removal of terminal $\alpha-1,2$ glucose residues from precursor oligosaccharides in the ER. A variety of viruses such as HIV, HSV and Dengue-virus have been shown to be highly sensitive to inhibitors of these enzymes (Mehta et al., 2001; Mehta et al., 2002). One of these inhibitors, castanopermine, has been demonstrated to inhibit replication of influenza virus A/Hongkong/11/88 in MDCK cells with an $\mathrm{IC}_{50}$ value of $<6 \mu \mathrm{M}$ (Klumpp, 2004b). The inhibitor also acted antiviral in vivo in a mouse model and reduced lung titers of A/PR8/34 infected mice by tenfold when administered intranasal. The compound has reached Phase II clinical trials for the treatment of HIV and has been licensed for a potential treatment of Hepatitis-C-virus infections (reviewed in (Klumpp, 2004b)).

Another important requirement for a cellular enzyme is the proteolytic cleavage of the HA by proteases. The infectivity and pathogenicity of influenza virus is based on the proteolytic cleavage of the precursor $\mathrm{HA}_{0}$ into $\mathrm{HA}_{1}$ and $\mathrm{HA}_{2}$ chains by an arginine-specific, trypsin-like host protease. 
Several exogenous protease inhibitors were investigated with respect to their anti-influenza activity: Camostat, a serine protease inhibitor; was shown to exhibit strong anti-influenza effects in vitro and in vivo in mice and in chicken embryos. The compound also showed strong anti-influenza effects in amantadine-resistant type-A and -B virus infection in vitro (Lee et al., 1996) .

Other protease inhibitors Nafamostat mesilate, camostat mesilate, gabexate mesilate and aprotinin also inhibited virus replication in vitro (Ovcharenko and Zhirnov, 1994) (reviewed in: Luscher-Mattli, 2000). The protease inhibitors Gordox, Contrycal and epsilonaminocapronic acid were tested in both animal and clinical experiments. Inhalation of aminocapronic acid-containing aerosols exerted the most effective therapeutic effect, reducing the duration of viral antigen in the nasopharyngeal epithelium $11 / 2$ to 2 fold (Zhirnov et al., 1984). Recombinant human mucus protease inhibitor (MPI) was investigated for its anti-viral activity in rat lungs in vitro. The C-, but not the N-terminal domain of MPI was shown to inhibit the proteolytic activity of tryptase Clara and of virus activation at $\mathrm{nM}$ concentrations (Beppu et al., 1997; Kido et al., 1999).

However, the current understanding is that protease inhibitors - mainly used in HIV therapy - may produce serious toxic side effects. Recent investigations showed that protease inhibitors can cause diabetes, hepatic and renal failures and mutagenic (potentially carcinogenic) effects. A further disadvantage of protease inhibitors is the rapid development of viral resistance, and a variable strain sensitivity to these anti-viral agents (discussed in: Luscher-Mattli, 2000). Nevertheless protease inhibitors are still under evaluation as potential anti-influenza therapeutics (Kido et al., 2004; Savarino, 2005).

\section{CONCLUSIONS}

Regarding the continues threat caused by seasonal flu-epidemics and the immanent danger of re-occurring pandemic outbreaks that both impose a great burden on human and animal health, and considering the fact, that influenza viruses can not be eradicated, the possibilities to fight this disease have been greatly improved by novel molecular biological techniques in recent years. Vaccination is still by far the best prophylactic measure, but new drugs, which attack the virus directly, will further support to combat these foes. Nevertheless the viral tactic to escape direct intervention by resistance is a major drawback of current therapeutic interventions. This 
problem might be overcome by innovative methods that target cellular functions essential for efficient virus replication

\section{ACKNOWLEDGEMENTS}

We would like to thank all the colleagues who have helped in many invaluable ways in the production of this chapter, in particular, Dr. C. Erhardt, Dr. W. Wurzer, H. Marjuki, B. Daubner, V. Oehlschlaeger, J. Lampe and K. Oesterle.

\section{NOTES}

This work is dedicated to Prof. Dr. C. Scholtissek's $75^{\text {th }}$ Birthday.

\section{REFERENCES}

Abramson, J. S., 1999, Intranasal, cold-adapted, live, attenuated influenza vaccine. Pediatr Infect Dis $J$ 18, 1103-4.

Appleyard, G., Monto, A. S., Gunn, R. A., Bandyk, M. G., and King, C. L., 1977, Amantadine-resistance as a genetic marker for influenza viruses. $J$ Gen Virol 36, 249-255.

Arora, D. J., and Gasse, N., 1998, Influenza virus hemagglutinin stimulates the protein kinase C activity of human polymorphonuclear leucocytes. Arch Virol 143, 2029-37.

Babai, I., Barenholz, Y., Zakay-Rones, Z., Greenbaum, E., Samira, S., Hayon, I., Rochman, M., and Kedar, E., 2001, A novel liposomal influenza vaccine (INFLUSOMEVAC) containing hemagglutinin-neuraminidase and IL-2 or GM-CSF induces protective anti-neuraminidase antibodies cross-reacting with a wide spectrum of influenza A viral strains. Vaccine 20, 505-15.

Balachandran, S., Roberts, P. C., Kipperman, T., Bhalla, K. N., Compans, R. W., Archer, D. R., and Barber, G. N., 2000, Alpha/beta interferons potentiate virus-induced apoptosis through activation of the FADD/Caspase-8 death signaling pathway. J Virol 74, 1513-23.

Barber, S. A., Bruett, L., Douglass, B. R., Herbst, D. S., Zink, M. C., and Clements, J. E., 2002, Visna virus-induced activation of MAPK is required for virus replication and correlates with virus-induced neuropathology. $J$ Virol 76, 817-28.

Bardiya, N., and Bae, J. H., 2005, Influenza vaccines: recent advances in production technologies. Appl Microbiol Biotechnol 67, 299-305.

Belshe, R. B., 2004, Current status of live attenuated influenza virus vaccine in the US. Virus Research 103, 177.

Belshe, R. B., Gruber, W. C., Mendelman, P. M., Mehta, H. B., Mahmood, K., Reisinger, K., Treanor, J., Zangwill, K., Hayden, F. G., Bernstein, D. I., Kotloff, K., King, J., 
Piedra, P. A., Block, S. L., Yan, L., and Wolff, M., 2000, Correlates of immune protection induced by live, attenuated, cold-adapted, trivalent, intranasal influenza virus vaccine. J Infect Dis 181, 1133-7.

Belshe, R. B., Mendelman, P. M., Treanor, J., King, J., Gruber, W. C., Piedra, P., Bernstein, D. I., Hayden, F. G., Kotloff, K., Zangwill, K., Iacuzio, D., and Wolff, M., 1998, The efficacy of live attenuated, cold-adapted, trivalent, intranasal influenzavirus vaccine in children. $N$ Engl $J$ Med 338, 1405-12.

Belshe, R. B., Nichol, K. L., Black, S. B., Shinefield, H., Cordova, J., Walker, R., Hessel, C., Cho, I., and Mendelman, P. M., 2004, Safety, efficacy, and effectiveness of live, attenuated, cold-adapted influenza vaccine in an indicated population aged 5-49 years. Clin Infect Dis 39, 920-7.

Ben-Yehuda, A., Joseph, A., Barenholz, Y., Zeira, E., Even-Chen, S., Louria-Hayon, I., Babai, I., Zakay-Rones, Z., Greenbaum, E., Galprin, I., Gluck, R., Zurbriggen, R., and Kedar, E., 2003a, Immunogenicity and safety of a novel IL-2-supplemented liposomal influenza vaccine (INFLUSOME-VAC) in nursing-home residents. Vaccine 21, 3169-78.

Ben-Yehuda, A., Joseph, A., Zeira, E., Even-Chen, S., Louria-Hayon, I., Babai, I., ZakayRones, Z., Greenbaum, E., Barenholz, Y., and Kedar, E., 2003b, Immunogenicity and safety of a novel liposomal influenza subunit vaccine (INFLUSOME-VAC) in young adults. J Med Virol 69, 560-7.

Beppu, Y., Imamura, Y., Tashiro, M., Towatari, T., Ariga, H., and Kido, H., 1997, Human mucus protease inhibitor in airway fluids is a potential defensive compound against infection with influenza A and Sendai viruses. J Biochem (Tokyo) 121, 309-16.

Beyer, W. E. P., Palache, A. M., de Jong, J. C., and Osterhaus, A. D. M. E., 2002, Cold-adapted live influenza vaccine versus inactivated vaccine: systemic vaccine reactions, local and systemic antibody response, and vaccine efficacy A metaanalysis. Vaccine 20, 1340.

Boivin, G., Goyette, N., Hardy, I., Aoki, F., Wagner, A., and Trottier, S., 2000, Rapid antiviral effect of inhaled zanamivir in the treatment of naturally occurring influenza in otherwise healthy adults. $J$ Infect Dis 181, 1471-1474.

Bowersock, T. L., and Martin, S., 1999, Vaccine delivery to animals. Adv Drug Deliv Rev 38, 167-194.

Boyce, T. G., and Poland, G. A., 2000, Promises and challenges of live-attenuated intranasal influenza vaccines across the age spectrum: a review. Biomed Pharmacother 54, 210-8.

Bridges, C. B., Harper, S. A., Fukuda, K., Uyeki, T. M., Cox, N. J., Singelton, J. A., and Practices, A. C. o. I., 2003, Prevention and control of influenza. Recommendations of the Advisory Committee on Immunization Practices (ACIP). MMWR Recomm Rep 52(PR-8), 1-34.

Brown, D. M., Roman, E., and Swain, S. L., 2004, CD4 T cell responses to influenza infection. Semin Immunol 16, 171-7.

Cai, H., Smola, U., Wixler, V., Eisenmann-Tappe, I., Diaz-Meco, M. T., Moscat, J., Rapp, U., and Cooper, G. M., 1997, Role of diacylglycerol-regulated protein kinase C isotypes in growth factor activation of the Raf-1 protein kinase. Mol Cell Biol 17, 732-41. 
Cass, L. M., Efthymiopoulos, C., and Bye, A., 1999, Pharmacokinetics of zanamivir after intravenous, oral, inhaled or intranasal administration to healthy volunteers. Clin Pharmacokinet 36 Suppl 1, 1-11.

Chand, P., Bantia, S., Kotian, P. L., El-Kattan, Y., Lin, T. H., and Babu, Y. S., 2005, Comparison of the anti-influenza virus activity of cyclopentane derivatives with oseltamivir and zanamivir in vivo. Bioorg Med Chem 13, 4071-7.

Chen, H., Deng, G., Li, Z., Tian, G., Li, Y., Jiao, P., Zhang, L., Liu, Z., Webster, R. G., and $\mathrm{Yu}, \mathrm{K} ., 2004$, The evolution of H5N1 influenza viruses in ducks in southern China. Proc Natl Acad Sci U S A 101, 10452-7.

Chen, H., Subbarao, K., Swayne, D., Chen, Q., Lu, X., Katz, J., Cox, N., and Matsuoka, Y., 2003, Generation and evaluation of a high-growth reassortant H9N2 influenza A virus as a pandemic vaccine candidate. Vaccine 21, 1974-9.

Chen, W., Calvo, P. A., Malide, D., Gibbs, J., Schubert, U., Bacik, I., Basta, S., O'Neill, R., Schickli, J., Palese, P., Henklein, P., Bennink, J. R., and Yewdell, J. W., 2001, A novel influenza A virus mitochondrial protein that induces cell death. Nat Med 7, 1306-12.

Chu, W. M., Ostertag, D., Li, Z. W., Chang, L., Chen, Y., Hu, Y., Williams, B., Perrault, J., and Karin, M., 1999, JNK2 and IKKbeta are required for activating the innate response to viral infection. Immunity 11, 721-31.

Claas, E. C., Osterhaus, A. D., van Beek, R., De Jong, J. C., Rimmelzwaan, G. F., Senne, D. A., Krauss, S., Shortridge, K. F., and Webster, R. G., 1998, Human influenza A H5N1 virus related to a highly pathogenic avian influenza virus. Lancet 351, 472-7.

Clements, M. L., and Murphy, B. R., 1986, Development and Persistence of Local and Systemic Antibody-Responses in Adults Given Live Attenuated Or Inactivated Influenza-A Virus-Vaccine. Journal of Clinical Microbiology 23, 66.

Cohen, G. M., 1997, Caspases: the executioners of apoptosis. Biochem J 326, 1-16.

Cohen, P. (2002): Protein kinases--the major drug targets of the twenty-first century? Nat Rev Drug Discov 1, 309-15.

Colman, P. M., Varghese, J. N., and Laver, W. G., 1983, Structure of the catalytic and antigenic sites in influenza virus neuraminidase. Nature 303, 41-44.

Compans, R. W., Dimmock, N. J., and Meier-Ewert, H., 1969, Effect of antibody to neuraminidase on the maturation and hemagglutinating activity of an influenza A2 virus. J Virol 4, 528-534.

Constantinescu, S. N., Cernescu, C. D., and Popescu, L. M., 1991, Effects of protein kinase C inhibitors on viral entry and infectivity. FEBS Lett 292, 31-3.

Couch, R. B., 2003, An overview of serum antibody responses to influenza virus antigens. Dev Biol 115, 25-30.

Couch, R. B., and Kasel, J. A., 1983, Immunity to influenza in man. Annu Rev Microbiol 37, 529-49.

Coulter, A., Harris, R., Davis, R., Drane, D., Cox, J., Ryan, D., Sutton, P., Rockman, S., and Pearse, M., 2003, Intranasal vaccination with ISCOMATRIX adjuvanted influenza vaccine. Vaccine 21, 946-9.

Courtois, G., Smahi, A., and Israel, A., 2001, NEMO/IKK gamma: linking NF-kappa B to human disease. Trends Mol Med 7, 427-30.

Cox, N. J., and Subbarao, K., 1999, Influenza. Lancet 354, 1277. 
Cox, R. J., Brokstad, K. A., and Ogra, P., 2004, Influenza virus: immunity and vaccination strategies. Comparison of the immune response to inactivated and live, attenuated influenza vaccines. Scand J Immunol 59, 1-15.

Dauber, B., Heins, G., and Wolff, T., 2004, The influenza B virus nonstructural NS1 protein is essential for efficient viral growth and antagonizes beta interferon induction. J Virol 78, 1865-72.

de Jong, J. C., Claas, E. C., Osterhaus, A. D., Webster, R. G., and Lim, W. L., 1997, A pandemic warning? Nature 389, 554.

de Jong, J. C., Palache, A. M., Beyer, W. E., Rimmelzwaan, G. F., Boon, A. C., and Osterhaus, A. D., 2003, Haemagglutinin-inhibiting antibody to influenza virus. Dev Biol 115, 63-73.

Delhase, M., and Karin, M., 1999, The I kappa B kinase: a master regulator of NF-kappa B, innate immunity, and epidermal differentiation. Cold Spring Harb Symp Quant Biol 64, 491-503.

Demicheli, V., Jefferson, T., Rivetti, D., and Deeks, J., 2000, Prevention and early treatment of influenza in healthy adults. Vaccine 18, 957-1030.

Dong, C., Davis, R. J., and Flavell, R. A., 2002, MAP kinases in the immune response. Annu Rev Immunol 20, 55-72.

Dumitru, C. D., Ceci, J. D., Tsatsanis, C., Kontoyiannis, D., Stamatakis, K., Lin, J. H., Patriotis, C., Jenkins, N. A., Copeland, N. G., Kollias, G., and Tsichlis, P. N., 2000, TNF-alpha induction by LPS is regulated posttranscriptionally via a Tpl2/ERKdependent pathway. Cell 103, 1071-83.

Edwards, K. M., Dupont, W. D., Westrich, M. K., Plummer, W. D., Jr., Palmer, P. S., and Wright, P. F., 1994, A randomized controlled trial of cold-adapted and inactivated vaccines for the prevention of influenza A disease. J Infect Dis 169, 68-76.

English, J., Pearson, G., Wilsbacher, J., Swantek, J., Karandikar, M., Xu, S., and Cobb, M. H., 1999, New insights into the control of MAP kinase pathways. Exp Cell Res 253, 255-70.

Faleiro, L., and Lazebnik, Y., 2000, Caspases disrupt the nuclear-cytoplasmic barrier. J Cell Biol 151, 951-9.

Ferko, B., Stasakova, J., Romanova, J., Kittel, C., Sereinig, S., Katinger, H., and Egorov, A., 2004, Immunogenicity and protection efficacy of replication-deficient influenza A viruses with altered NS1 genes. J Virol 78, 13037-45.

Fesq, H., Bacher, M., Nain, M., and Gemsa, D., 1994, Programmed cell death (apoptosis) in human monocytes infected by influenza A virus. Immunobiology 190, 175-82.

Flory, E., Kunz, M., Scheller, C., Jassoy, C., Stauber, R., Rapp, U. R., and Ludwig, S., 2000, Influenza virus-induced NF-kappaB-dependent gene expression is mediated by overexpression of viral proteins and involves oxidative radicals and activation of IkappaB kinase. J Biol Chem 275, 8307-14.

Fodor, E., Devenish, L., Engelhardt, O. G., Palese, P., Brownlee, G. G., and Garcia-Sastre, A., 1999, Rescue of influenza A virus from recombinant DNA. J Virol 73, 9679-82.

Fouchier, R. A., Schneeberger, P. M., Rozendaal, F. W., Broekman, J. M., Kemink, S. A., Munster, V., Kuiken, T., Rimmelzwaan, G. F., Schutten, M., Van Doornum, G. J., Koch, G., Bosman, A., Koopmans, M., and Osterhaus, A. D., 2004, Avian influenza A virus (H7N7) associated with human conjunctivitis and a fatal case of acute respiratory distress syndrome. Proc Natl Acad Sci U S A 101, 1356-61. 
Fujimoto, I., Takizawa, T., Ohba, Y., and Nakanishi, Y., 1998, Co-expression of Fas and Fasligand on the surface of influenza virus-infected cells. Cell Death Differ 5, 426-31.

Furuta, Y., Takahashi, K., Fukuda, Y., Kuno, M., Kamiyama, T., Kozaki, K., Nomura, N., Egawa, H., Minami, S., Watanabe, Y., Narita, H., and Shiraki, K., 2002, In vitro and in vivo activities of anti-influenza virus compound T-705. Antimicrob Agents Chemother 46, 977-81.

Furuta, Y., Takahashi, K., Kuno-Maekawa, M., Sangawa, H., Uehara, S., Kozaki, K., Nomura, N., Egawa, H., and Shiraki, K., 2005, Mechanism of action of T-705 against influenza virus. Antimicrob Agents Chemother 49, 981-6.

Galarza, J. M., Latham, T., and Cupo, A., 2005, Virus-like particle vaccine conferred complete protection against a lethal influenza virus challenge. Viral Immunol 18, 365-72.

Garcia-Sastre, A., 1998, Negative-strand RNA viruses: applications to biotechnology. Trends Biotechnol 16, 230-5.

Garcia-Sastre, A., Durbin, R. K., Zheng, H., Palese, P., Gertner, R., Levy, D. E., and Durbin, J. E., 1998a, The role of interferon in influenza virus tissue tropism. $J$ Virol 72, 8550-8.

Garcia-Sastre, A., Egorov, A., Matassov, D., Brandt, S., Levy, D. E., Durbin, J. E., Palese, P., and Muster, T., 1998b, Influenza A virus lacking the NS1 gene replicates in interferon-deficient systems. Virology 252, 324-30.

Garrington, T. P., and Johnson, G. L., 1999, Organization and regulation of mitogen-activated protein kinase signaling pathways. Curr Opin Cell Biol 11, 211-8.

Ghosh, S. (1999): Regulation of inducible gene expression by the transcription factor NFkappaB. Immunol Res 19, 183-9.

Gil, J., Alcami, J., and Esteban, M., 2000, Activation of NF-kappa B by the dsRNAdependent protein kinase, PKR involves the I kappa B kinase complex. Oncogene 19, 1369-78.

GlaxoWellcome, 2001, Relenza ${ }^{\mathrm{TM}}$ product information.

Glezen, W. P., 2004, Control of influenza. Tex Heart Inst J 31, 39-41.

Gluck, R., Moser, C., and Metcalfe, I. C., 2004, Influenza virosomes as an efficient system for adjuvanted vaccine delivery. Expert Opin Biol Ther 4, 1139-45.

Gubareva, L. V., 2004, Molecular mechanisms of influenza virus resistance to neuraminidase inhibitors. Virus Res 103, 199-203.

Gubareva, L. V., Kaiser, L., Matrosovich, M. N., Soo-Hoo, Y., and Hayden, F. G., 2001, Selection of influenza virus mutants in experimentally infected volunteers treated with oseltamivir. J Infect Dis 183, 523-531.

Gubareva, L. V., Matrosovich, M. N., Brenner, M. K., Bethell, R. C., and Webster, R. G., 1998, Evidence for zanamivir resistance in an immunocompromised child infected with influenza B virus. J Infect Dis 178, 1257-1262.

Hall, C. B., Dolin, R., Gala, C. L., Markovitz, D. M., Zhang, Y. Q., Madore, P. H., Disney, F. A., Talpey, W. B., Green, J. L., Francis, A. B., and et al., 1987, Children with influenza A infection: treatment with rimantadine. Pediatrics 80, 275-282.

Harper, S. A., Fukuda, K., Uyeki, T. M., Cox, N. J., and Bridges, C. B., 2004, Prevention and control of influenza: recommendations of the Advisory Committee on Immunization Practices (ACIP). MMWR Recomm Rep 53, 1-40. 
Hastings, J. C., Selnick, H., Wolanski, B., and Tomassini, J. E., 1996, Anti-influenza virus activities of 4-substituted 2,4-dioxobutanoic acid inhibitors. Antimicrob Agents Chemother 40, 1304-7.

Hatta, M., Goto, H., and Kawaoka, Y., 2004, Influenza B virus requires BM2 protein for replication. J Virol 78, 5576-83.

Hatta, M., and Kawaoka, Y., 2002, The continued pandemic threat posed by avian influenza viruses in Hong Kong. Trends Microbiol 10, 340-4.

Hayden, F. G., Atmar, R. L., Schilling, M., Johnson, C., Poretz, D., Paar, D., Huson, L., Ward, P., and Mills, R. G., 1999a, Use of the selective oral neuraminidase inhibitor oseltamivir to prevent influenza. $N$ Engl J Med 341, 1336-1343.

Hayden, F. G., Belshe, R. B., Clover, R. D., Hay, A. J., Oakes, M. G., and Soo, W., 1989, Emergence and apparent transmission of rimantadine-resistant influenza A virus in families. N Engl J Med 321, 1696-1702.

Hayden, F. G., Cote, K. M., and Douglas, R. G., Jr., 1980, Plaque inhibition assay for drug susceptibility testing of influenza viruses. Antimicrob Agents Chemother 17, 865870.

Hayden, F. G., Gubareva, L. V., Monto, A. S., Klein, T. C., Elliot, M. J., Hammond, J. M., Sharp, S. J., and Ossi, M. J., 2000, Inhaled zanamivir for the prevention of influenza in families. Zanamivir Family Study Group. N Engl J Med 343, 1282-1289.

Hayden, F. G., Osterhaus, A. D., Treanor, J. J., Fleming, D. M., Aoki, F. Y., Nicholson, K. G., Bohnen, A. M., Hirst, H. M., Keene, O., and Wightman, K., 1997, Efficacy and safety of the neuraminidase inhibitor zanamivir in the treatment of influenzavirus infections. GG167 Influenza Study Group. N Engl J Med 337, 874-880.

Hayden, F. G., Treanor, J. J., Betts, R. F., Lobo, M., Esinhart, J. D., and Hussey, E. K., 1996, Safety and efficacy of the neuraminidase inhibitor GG167 in experimental human influenza. Jama 275, 295-299.

Hayden, F. G., Treanor, J. J., Fritz, R. S., Lobo, M., Betts, R. F., Miller, M., Kinnersley, N., Mills, R. G., Ward, P., and Straus, S. E., 1999b, Use of the oral neuraminidase inhibitor oseltamivir in experimental human influenza: randomized controlled trials for prevention and treatment. Jama 282, 1240-1246.

Hazzalin, C. A., and Mahadevan, L. C., 2002, MAPK-regulated transcription: a continuously variable gene switch? Nat Rev Mol Cell Biol 3, 30-40.

Hinshaw, V. S., Olsen, C. W., Dybdahl-Sissoko, N., and Evans, D., 1994, Apoptosis: a mechanism of cell killing by influenza A and B viruses. J Virol 68, 3667-73.

Hiscott, J., Kwon, H., and Genin, P., 2001, Hostile takeovers: viral appropriation of the NFkappaB pathway. J Clin Invest 107, 143-51.

Hiscott, J., Pitha, P., Genin, P., Nguyen, H., Heylbroeck, C., Mamane, Y., Algarte, M., and Lin, R., 1999, Triggering the interferon response: the role of IRF-3 transcription factor. J Interferon Cytokine Res 19, 1-13.

Horimoto, T., Iwatsuki-Horimoto, K., Hatta, M., and Kawaoka, Y. (2004): Influenza A viruses possessing type $\mathrm{B}$ hemagglutinin and neuraminidase: potential as vaccine components. Microbes Infect 6, 579-83.

Horimoto, T., and Kawaoka, Y., 2001, Pandemic threat posed by avian influenza A viruses. Clin Microbiol Rev 14, 129-49.

Hufnagel, L., Brockmann, D., and Geisel, T., 2004, Forecast and control of epidemics in a globalized world. Proc Natl Acad Sci U S A 101, 15124-9. 
Ito, T., Kobayashi, Y., Morita, T., Horimoto, T., and Kawaoka, Y., 2002, Virulent influenza A viruses induce apoptosis in chickens. Virus Res 84, 27-35.

Jackson, D., Zurcher, T., and Barclay, W., 2004, Reduced incorporation of the influenza B virus BM2 protein in virus particles decreases infectivity. Virology 322, 276-85.

Jackson, L. A., Holmes, S. J., Mendelman, P. M., Huggins, L., Cho, I., and Rhorer, J., 1999, Safety of a trivalent live attenuated intranasal influenza vaccine, FluMist, administered in addition to parenteral trivalent inactivated influenza vaccine to seniors with chronic medical conditions. Vaccine 17, 1905-9.

Janicke, R. U., Sprengart, M. L., Wati, M. R., and Porter, A. G., 1998, Caspase-3 is required for DNA fragmentation and morphological changes associated with apoptosis. $J$ Biol Chem 273, 9357-60.

Jin, H., Lu, B., Zhou, H., Ma, C. H., Zhao, J., Yang, C. F., Kemble, G., and Greenberg, H,. 2003, Multiple amino acid residues confer temperature sensitivity to human influenza virus vaccine strains (FluMist) derived from cold-adapted A/Ann Arbor/6/60. Virology 306, 18.

Jones, T., Stern, A., and Lin, R., 1994, Potential role of granulocyte-macrophage colonystimulating factor as vaccine adjuvant. Eur J Clin Microbiol Infect Dis 13 Suppl 2, S47-53.

Joseph, A., Louria-Hayon, I., Plis-Finarov, A., Zeira, E., Zakay-Rones, Z., Raz, E., Hayashi, T., Takabayashi, K., Barenholz, Y., and Kedar, E., 2002, Liposomal immunostimulatory DNA sequence (ISS-ODN): an efficient parenteral and mucosal adjuvant for influenza and hepatitis B vaccines. Vaccine 20, 3342-54.

Julkunen, I., Melen, K., Nyqvist, M., Pirhonen, J., Sareneva, T., and Matikainen, S., 2000, Inflammatory responses in influenza A virus infection. Vaccine 19, S32-7.

Justewicz, D. M., Morin, M. J., Robinson, H. L., and Webster, R. G., 1995, Antibodyforming cell response to virus challenge in mice immunized with DNA encoding the influenza virus hemagglutinin. $J$ Virol 69, 7712-7.

Karin, M., 1999a, The beginning of the end: IkappaB kinase (IKK) and NF-kappaB activation. $J$ Biol Chem 274, 27339-42.

Karin, M., 1999b, How NF-kappaB is activated: the role of the IkappaB kinase (IKK) complex. Oncogene 18, 6867-74.

Karin, M., and Ben-Neriah, Y., 2000, Phosphorylation meets ubiquitination: the control of NF-[kappa]B activity. Annu Rev Immunol 18, 621-63.

Kati, W. M., Montgomery, D., Carrick, R., Gubareva, L., Maring, C., McDaniel, K., Steffy, K., Molla, A., Hayden, F., Kempf, D., and Kohlbrenner, W., 2002, In vitro characterization of A-315675, a highly potent inhibitor of A and B strain influenza virus neuraminidases and influenza virus replication. Antimicrob Agents Chemother 46, 1014-21.

Kemble, G., and Greenberg, H., 2003, Novel generations of influenza vaccines. Vaccine 21, 1789.

Kendal, A. P., 1997, Cold-adapted live attenuated influenza vaccines developed in Russia: can they contribute to meeting the needs for influenza control in other countries? Eur J Epidemiol 13, 591-609.

Kerr, J. F., Wyllie, A. H., and Currie, A. R., 1972, Apoptosis: a basic biological phenomenon with wide-ranging implications in tissue kinetics. Br J Cancer 26, 239-57. 
Kido, H., Beppu, Y., Imamura, Y., Chen, Y., Murakami, M., Oba, K., and Towatari, T., 1999, The human mucus protease inhibitor and its mutants are novel defensive compounds against infection with influenza A and Sendai viruses. Biopolymers 51, 79-86.

Kido, H., Okumura, Y., Yamada, H., Mizuno, D., Higashi, Y., and Yano, M., 2004, Secretory leukoprotease inhibitor and pulmonary surfactant serve as principal defenses against influenza A virus infection in the airway and chemical agents up-regulating their levels may have therapeutic potential. Biol Chem 385, 1029-34.

Kim, C. U., Lew, W., Williams, M. A., Liu, H., Zhang, L., Swaminathan, S., Bischofberger, N., Chen, M. S., Mendel, D. B., Tai, C. Y., Laver, W. G., and Stevens, R. C., 1997, Influenza neuraminidase inhibitors possessing a novel hydrophobic interaction in the enzyme active site: Design, synthesis, and structural analysis of carbocyclic sialic acid analogues with potent anti-influenza activity. J. Am. Chem. Soc. 119, 681-690.

Kim, C. U., Lew, W., Williams, M. A., Wu, H., Zhang, L., Chen, X., Escarpe, P. A., Mendel, D. B., Laver, W. G., and Stevens, R. C., 1998, Structure-activity relationship studies of novel carbocyclic influenza neuraminidase inhibitors. $J$ Med Chem 41, 24512460.

King, J. C., Jr., Lagos, R., Bernstein, D. I., Piedra, P. A., Kotloff, K., Bryant, M., Cho, I., and Belshe, R. B., 1998, Safety and immunogenicity of low and high doses of trivalent live cold-adapted influenza vaccine administered intranasally as drops or spray to healthy children. $J$ Infect Dis 177, 1394-7.

Kiso, M., Mitamura, K., Sakai-Tagawa, Y., Shiraishi, K., Kawakami, C., Kimura, K., Hayden, F. G., Sugaya, N., and Kawaoka, Y., 2004, Resistant influenza A viruses in children treated with oseltamivir: descriptive study. Lancet 364, 759-65.

Kistner, O., Barrett, P. N., Mundt, W., Reiter, M., Schober-Bendixen, S., and Dorner, F., 1998, Development of a mammalian cell (Vero) derived candidate influenza virus vaccine. Vaccine 16, 960.

Klumpp, K., 2004a, Recent advances in the discovery and development of anti-influenza drugs. Expert Opinion on Therapeutic Patents 14, 1153-1168.

Klumpp, K., 2004b, Recent advances in the discovery and development of anti-influenza drugs. Expert Opin. Ther. Patents 14, 1153-1168.

Kolch, W., Heidecker, G., Kochs, G., Hummel, R., Vahidi, H., Mischak, H., Finkenzeller, G., Marme, D., and Rapp, U. R., 1993, Protein kinase C alpha activates RAF-1 by direct phosphorylation. Nature 364, 249-52.

Koopmans, M., Wilbrink, B., Conyn, M., Natrop, G., van der Nat, H., Vennema, H., Meijer, A., van Steenbergen, J., Fouchier, R., Osterhaus, A., and Bosman, A., 2004, Transmission of H7N7 avian influenza A virus to human beings during a large outbreak in commercial poultry farms in the Netherlands. Lancet 363, 587-93.

Kujime, K., Hashimoto, S., Gon, Y., Shimizu, K., and Horie, T., 2000, p38 mitogen-activated protein kinase and c-jun-NH2-terminal kinase regulate RANTES production by influenza virus-infected human bronchial epithelial cells. J Immunol 164, 3222-8.

Kunzelmann, K., Beesley, A. H., King, N. J., Karupiah, G., Young, J. A., and Cook, D. I., 2000, Influenza virus inhibits amiloride-sensitive $\mathrm{Na}+$ channels in respiratory epithelia. Proc Natl Acad Sci U S A 97, 10282-7. 
LaForce, F. M., Nichol, K. L., and Cox, N. J., 1994, Influenza: virology, epidemiology, disease, and prevention. Am J Prev Med 10 Suppl, 31-44.

Lamb, R. A., and Krug, R. M., 2001, Orthomyxoviridae: The viruses and their replication, pp. 1487-1531. In D. M. Knipe, P. M. Howley, and D. E. Griffin (Eds): Fields Virology, Lippencott Williams \& Williams.

Langley, J. M., and Faughnan, M. E., 2004, Prevention of influenza in the general population. Canadian Medical Association Journal 171, 1213.

Lee, F. S., Peters, R. T., Dang, L. C., and Maniatis, T., 1998, MEKK1 activates both IkappaB kinase alpha and IkappaB kinase beta. Proc Natl Acad Sci U S A 95, 9319-24.

Lee, M. G., Kim, K. H., Park, K. Y., and Kim, J. S., 1996, Evaluation of anti-influenza effects of camostat in mice infected with non-adapted human influenza viruses. Arch Virol 141, 1979-89.

Li, K. S., Guan, Y., Wang, J., Smith, G. J., Xu, K. M., Duan, L., Rahardjo, A. P., Puthavathana, P., Buranathai, C., Nguyen, T. D., Estoepangestie, A. T., Chaisingh, A., Auewarakul, P., Long, H. T., Hanh, N. T., Webby, R. J., Poon, L. L., Chen, H., Shortridge, K. F., Yuen, K. Y., Webster, R. G., and Peiris, J. S., 2004, Genesis of a highly pathogenic and potentially pandemic H5N1 influenza virus in eastern Asia. Nature 430, 209-13.

Li, M. L., Rao, P., and Krug, R. M., 2001, The active sites of the influenza cap-dependent endonuclease are on different polymerase subunits. Embo J 20, 2078-86.

Li, S. Q., Liu, C. G., Klimov, A., Subbarao, K., Perdue, M. L., Mo, D., Ji, Y. Y., Woods, L., Hietala, S., and Bryant, M., 1999, Recombinant influenza A virus vaccines for the pathogenic human A Hong Kong 97 (H5N1) viruses. Journal of Infectious Diseases 179, 1132.

Li, W., Escarpe, P. A., Eisenberg, E. J., Cundy, K. C., Sweet, C., Jakeman, K. J., Merson, J., Lew, W., Williams, M., Zhang, L., Kim, C. U., Bischofberger, N., Chen, M. S., and Mendel, D. B., 1998, Identification of GS 4104 as an orally bioavailable prodrug of the influenza virus neuraminidase inhibitor GS 4071. Antimicrob Agents Chemother 42, 647-653.

Lin, C., Holland, R. E., Jr., Donofrio, J. C., McCoy, M. H., Tudor, L. R., and Chambers, T. M., 2002, Caspase activation in equine influenza virus induced apoptotic cell death. Vet Microbiol 84, 357-65.

Lin, R., Heylbroeck, C., Pitha, P. M., and Hiscott, J., 1998, Virus-dependent phosphorylation of the IRF-3 transcription factor regulates nuclear translocation, transactivation potential, and proteasome-mediated degradation. Mol Cell Biol 18, 2986-96.

Lipatov, A. S., Govorkova, E. A., Webby, R. J., Ozaki, H., Peiris, M., Guan, Y., Poon, L., and Webster, R. G. (2004): Influenza: emergence and control. J Virol 78, 8951-9.

Liu, M., Wood, J. M., Ellis, T., Krauss, S., Seiler, P., Johnson, C., Hoffmann, E., Humberd, J., Hulse, D., Zhang, Y., Webster, R. G., and Perez, D. R., 2003, Preparation of a standardized, efficacious agricultural $\mathrm{H} 5 \mathrm{~N} 3$ vaccine by reverse genetics. Virology 314, 580-90.

Ljungberg, K., Wahren, B., Almqvist, J., Hinkula, J., Linde, A., and Winberg, G., 2000, Effective construction of DNA vaccines against variable influenza genes by homologous recombination. Virology 268, 244-50.

Lowy, R. J., 2003, Influenza virus induction of apoptosis by intrinsic and extrinsic mechanisms. Int Rev Immunol 22, 425-49. 
Ludwig, S., Ehrhardt, C., Neumeier, E. R., Kracht, M., Rapp, U. R., and Pleschka, S., 2001, Influenza virus-induced AP-1-dependent gene expression requires activation of the JNK signaling pathway. J Biol Chem 276, 10990-8.

Ludwig, S., Planz, O., Pleschka, S., and Wolff, T., 2003, Influenza-virus-induced signaling cascades: targets for antiviral therapy? Trends Mol Med 9, 46-52.

Ludwig, S., Pleschka, S., and Wolff, T., 1999, A fatal relationship-influenza virus interactions with the host cell. Viral Immunol 12, 175-96.

Ludwig, S., Wolff, T., Ehrhardt, C., Wurzer, W. J., Reinhardt, J., Planz, O., and Pleschka, S., 2004, MEK inhibition impairs influenza B virus propagation without emergence of resistant variants. FEBS Lett 561, 37-43.

Luo, H., Yanagawa, B., Zhang, J., Luo, Z., Zhang, M., Esfandiarei, M., Carthy, C., Wilson, J. E., Yang, D., and McManus, B. M., 2002, Coxsackievirus B3 replication is reduced by inhibition of the extracellular signal-regulated kinase (ERK) signaling pathway. $J$ Virol 76, 3365-73.

Luscher-Mattli, M., 2000, Influenza chemotherapy: a review of the present state of art and of new drugs in development. Arch Virol 145, 2233-48.

Maassab, H. F., and Bryant, M. L., 1999, The development of live attenuated cold-adapted influenza virus vaccine for humans. Rev Med Virol 9, 237-44.

Makela, M. J., Pauksens, K., Rostila, T., Fleming, D. M., Man, C. Y., Keene, O. N., and Webster, A., 2000, Clinical efficacy and safety of the orally inhaled neuraminidase inhibitor zanamivir in the treatment of influenza: a randomized, double-blind, placebo-controlled European study. J Infect 40, 42-48.

Maniatis, T., Falvo, J. V., Kim, T. H., Kim, T. K., Lin, C. H., Parekh, B. S., and Wathelet, M. G., 1998, Structure and function of the interferon-beta enhanceosome. Cold Spring Harb Symp Quant Biol 63, 609-20.

Maruoka, S., Hashimoto, S., Gon, Y., Nishitoh, H., Takeshita, I., Asai, Y., Mizumura, K., Shimizu, K., Ichijo, H., and Horie, T., 2003, ASK1 regulates influenza virus infection-induced apoptotic cell death. Biochem Biophys Res Commun 307, 870-6.

Matrosovich, M., Matrosovich, T., Carr, J., Roberts, N. A., and Klenk, H. D., 2003, Overexpression of the alpha-2,6-sialyltransferase in MDCK cells increases influenza virus sensitivity to neuraminidase inhibitors. $J$ Virol 77, 8418-25.

Matrosovich, M. N., Matrosovich, T. Y., Gray, T., Roberts, N. A., and Klenk, H. D., 2004, Neuraminidase is important for the initiation of influenza virus infection in human airway epithelium. $J$ Virol 78, 12665-7.

McClellan, K., and Perry, C. M., 2001, Oseltamivir: a review of its use in influenza. Drugs 61, 263-283.

McKimm-Breschkin, J., Trivedi, T., Hampson, A., Hay, A., Klimov, A., Tashiro, M., Hayden, F., and Zambon, M., 2003, Neuraminidase sequence analysis and susceptibilities of influenza virus clinical isolates to zanamivir and oseltamivir. Antimicrob Agents Chemother 47, 2264-72.

McKimm-Breschkin, J. L., 2000, Resistance of influenza viruses to neuraminidase inhibitorsa review. Antiviral Res 47, 1-17.

McMichael, A. J., Gotch, F. M., Noble, G. R., and Beare, P. A., 1983, Cytotoxic T-cell immunity to influenza. N Engl J Med 309, 13-7. 
McMichael, A. J., Michie, C. A., Gotch, F. M., Smith, G. L., and Moss, B., 1986, Recognition of influenza A virus nucleoprotein by human cytotoxic T lymphocytes. J Gen Virol 67 (Pt 4), 719-26.

Mehta, A., Carrouee, S., Conyers, B., Jordan, R., Butters, T., Dwek, R. A., and Block, T. M., 2001, Inhibition of hepatitis B virus DNA replication by imino sugars without the inhibition of the DNA polymerase: therapeutic implications. Hepatology 33, 148895.

Mehta, A., Ouzounov, S., Jordan, R., Simsek, E., Lu, X., Moriarty, R. M., Jacob, G., Dwek, R. A., and Block, T. M., 2002, Imino sugars that are less toxic but more potent as antivirals, in vitro, compared with N-n-nonyl DNJ. Antivir Chem Chemother 13, 299-304.

Meindl, P., Bodo, G., Palese, P., Schulman, J., and Tuppy, H., 1974, Inhibition of neuraminidase activity by derivatives of 2-deoxy-2,3-dehydro-N-acetylneuraminic acid. Virology 58, 457-463.

Mendel, D. B., Tai, C. Y., Escarpe, P. A., Li, W., Sidwell, R. W., Huffman, J. H., Sweet, C., Jakeman, K. J., Merson, J., Lacy, S. A., Lew, W., Williams, M. A., Zhang, L., Chen, M. S., Bischofberger, N., and Kim, C. U., 1998, Oral administration of a prodrug of the influenza virus neuraminidase inhibitor GS 4071 protects mice and ferrets against influenza infection. Antimicrob Agents Chemother 42, 640-646.

Mendelman, P. M., Cordova, J., and Cho, I., 2001, Safety, efficacy and effectiveness of the influenza virus vaccine, trivalent, types A and B, live, cold-adapted (CAIV-T) in healthy children and healthy adults. Vaccine 19, 2221-6.

Monto, A. S., Fleming, D. M., Henry, D., de Groot, R., Makela, M., Klein, T., Elliott, M., Keene, O. N., and Man, C. Y., 1999, Efficacy and safety of the neuraminidase inhibitor zanamivir in the treatment of influenza $\mathrm{A}$ and $\mathrm{B}$ virus infections. $J$ Infect Dis 180, 254-261.

Mori, I., Goshima, F., Koshizuka, T., Koide, N., Sugiyama, T., Yoshida, T., Yokochi, T., Nishiyama, Y., and Kimura, Y., 2003, Differential activation of the c-Jun Nterminal kinase/stress-activated protein kinase and p38 mitogen-activated protein kinase signal transduction pathways in the mouse brain upon infection with neurovirulent influenza A virus. J Gen Virol 84, 2401-2408.

Mori, I., Komatsu, T., Takeuchi, K., Nakakuki, K., Sudo, M., and Kimura, Y., 1995, In vivo induction of apoptosis by influenza virus. J Gen Virol 76, 2869-73.

Murphy, B. R., and Coelingh, K., 2002, Principles underlying the development and use of live attenuated cold-adapted influenza A and B virus vaccines. Viral Immunol 15, 295323.

Murphy, B. R., Park, E. J., Gottlieb, P., and Subbarao, K., 1997, An influenza A live attenuated reassortant virus possessing three temperature-sensitive mutations in the PB2 polymerase gene rapidly loses temperature sensitivity following replication in hamsters. Vaccine 15, 1372-8.

Muster, T., Subbarao, E. K., Enami, M., Murphy, B. R., and Palese, P., 1991, An influenza A virus containing influenza $B$ virus 5 ' and 3 ' noncoding regions on the neuraminidase gene is attenuated in mice. Proc Natl Acad Sci U S A 88, 5177-81.

N.N., 1985, Current status of amantadine and rimantadine as anti-influenza-A agents: memorandum from a WHO meeting. Bull World Health Organ 63, 51-56. 
Nemoto, S., DiDonato, J. A., and Lin, A., 1998, Coordinate regulation of IkappaB kinases by mitogen-activated protein kinase kinase kinase 1 and NF-kappaB-inducing kinase. Mol Cell Biol 18, 7336-43.

Neumann, G., Hughes, M. T., and Kawaoka, Y., 2000, Influenza A virus NS2 protein mediates vRNP nuclear export through NES-independent interaction with hCRM1. Embo J 19, 6751-8.

Neumann, G., and Kawaoka, Y., 1999, Genetic engineering of influenza and other negativestrand RNA viruses containing segmented genomes. Adv Virus Res 53, 265-300.

Neumann, G., Watanabe, T., Ito, H., Watanabe, S., Goto, H., Gao, P., Hughes, M., Perez, D. R., Donis, R., Hoffmann, E., Hobom, G., and Kawaoka, Y., 1999, Generation of influenza A viruses entirely from cloned cDNAs. Proc Natl Acad Sci U S A 96, 9345-50.

Nichol, K. L., 2001, Live attenuated influenza virus vaccines: new options for the prevention of influenza. Vaccine 19, 4373-7.

Nichol, K. L., Wuorenma, J., and von Sternberg, T., 1998, Benefits of influenza vaccination for low-, intermediate-, and high-risk senior citizens. Archives of Internal Medicine 158, 1769.

Nicholson, K. G., Aoki, F. Y., Osterhaus, A. D., Trottier, S., Carewicz, O., Mercier, C. H., Rode, A., Kinnersley, N., and Ward, P., 2000, Efficacy and safety of oseltamivir in treatment of acute influenza: a randomised controlled trial. Neuraminidase Inhibitor Flu Treatment Investigator Group. Lancet 355, 1845-1850.

Nimmerjahn, F., Dudziak, D., Dirmeier, U., Hobom, G., Riedel, A., Schlee, M., Staudt, L. M., Rosenwald, A., Behrends, U., Bornkamm, G. W., and Mautner, J., 2004, Active NF-kappaB signalling is a prerequisite for influenza virus infection. $J$ Gen Virol $\mathbf{8 5}$, 2347-56.

Nugent, K. M., and Shanley, J. D., 1984, Verapamil inhibits influenza A virus replication. Arch Virol 81, 163-70.

O'Neill, R. E., Talon, J., and Palese, P., 1998, The influenza virus NEP (NS2 protein) mediates the nuclear export of viral ribonucleoproteins. Embo J 17, 288-96.

Olschlager, V., Pleschka, S., Fischer, T., Rziha, H. J., Wurzer, W., Stitz, L., Rapp, U. R., Ludwig, S., and Planz, O., 2004, Lung-specific expression of active Raf kinase results in increased mortality of influenza A virus-infected mice. Oncogene 23, 6639-46.

Olsen, C. W., Kehren, J. C., Dybdahl-Sissoko, N. R., and Hinshaw, V. S., 1996, bcl-2 alters influenza virus yield, spread, and hemagglutinin glycosylation. $J$ Virol 70, 663-6.

Osterhaus, A. D., and Rimmelzwaan, G. F. (1998): Induction of virus-specific immunity by iscoms. Dev Biol Stand 92, 49-58.

Ovcharenko, A. V., and Zhirnov, O. P., 1994 Aprotinin aerosol treatment of influenza and paramyxovirus bronchopneumonia of mice. Antiviral Res 23, 107-18.

Oxford, J. S., Logan, I. S., and Potter, C. W., 1970, In vivo selection of an influenza A2 strain resistant to amantadine. Nature 226, 82-83.

Ozaki, H., Govorkova, E. A., Li, C., Xiong, X., Webster, R. G., and Webby, R. J., 2004, Generation of high-yielding influenza A viruses in African green monkey kidney (Vero) cells by reverse genetics. $J$ Virol 78, 1851-7.

Pahl, H. L., 1999, Activators and target genes of Rel/NF-kappaB transcription factors. Oncogene 18, 6853-66. 
Palese, P., and Compans, R. W., 1976, Inhibition of influenza virus replication in tissue culture by 2-deoxy-2,3-dehydro-N-trifluoroacetylneuraminic acid (FANA): mechanism of action. J Gen Virol 33, 159-163.

Palese, P., and Garcia-Sastre, A., 2002, Influenza vaccines: present and future. J Clin Invest 110, 9-13.

Palese, P., Muster, T., Zheng, H., O'Neill, R., and Garcia-Sastre, A., 1999, Learning from our foes: a novel vaccine concept for influenza virus. Arch Virol Suppl 15, 131-8.

Palese, P., and Schulman, J., 1977, Inhibitors of viral neuraminidase as potential antiviral drugs, pp. 189-205. In J. S. Oxford (Ed.): Chemoprophylaxis and virus infections of the upper respiratory tract, CRC Press, Boca Raton.

Palese, P., Tobita, K., Ueda, M., and Compans, R. W., 1974, Characterization of temperature sensitive influenza virus mutants defective in neuraminidase. Virology 61, 397-410.

Palese, P., Zheng, H., Engelhardt, O. G., Pleschka, S., and Garcia-Sastre, A., 1996, Negativestrand RNA viruses: genetic engineering and applications. Proc Natl Acad Sci U S A 93, 11354-8.

Parkes, K. E., Ermert, P., Fassler, J., Ives, J., Martin, J. A., Merrett, J. H., Obrecht, D., Williams, G., and Klumpp, K., 2003, Use of a pharmacophore model to discover a new class of influenza endonuclease inhibitors. J Med Chem 46, 1153-64.

Parkin, N. T., Chiu, P., and Coelingh, K., 1997, Genetically engineered live attenuated influenza A virus vaccine candidates. $J$ Virol 71, 2772-8.

Pau, M. G., Ophorst, C., Koldijk, M. H., Schouten, G., Mehtali, M., and Uytdehaag, F., 2001 The human cell line PER.C6 provides a new manufacturing system for the production of influenza vaccines. Vaccine 19, 2716.

Pinto, L. H., Lamb, R. A., and Holsinger, L. J., 1995, Understanding the mechanism of action of the anti-influenza virus drug amantadine. Trends Microbiol 3, 271. The wild-type M2 channel was found to be regulated by $\mathrm{pH}$. The wild-type M2 ion channel activity is proposed to have a pivotal role in the biology of influenza virus infection.

Planz, O., Pleschka, S., and Ludwig, S., 2001, MEK-specific inhibitor U0126 blocks spread of Borna disease virus in cultured cells. $J$ Virol 75, 4871-7.

Pleschka, S., Jaskunas, R., Engelhardt, O. G., Zurcher, T., Palese, P., and Garcia-Sastre, A., 1996, A plasmid-based reverse genetics system for influenza A virus. $J$ Virol 70, 4188-92.

Pleschka, S., Wolff, T., Ehrhardt, C., Hobom, G., Planz, O., Rapp, U. R., and Ludwig, S., 2001, Influenza virus propagation is impaired by inhibition of the Raf/MEK/ERK signalling cascade. Nat Cell Biol 3, 301-5.

Podda, A., 2001, The adjuvanted influenza vaccines with novel adjuvants: experience with the MF59-adjuvanted vaccine. Vaccine 19, 2673-80.

Potter, C. W., and Oxford, J. S., 1979, Determinants of Immunity to Influenza Infection in Man. British Medical Bulletin 35, 69.

Puthavathana, P., Auewarakul, P., Charoenying, P. C., Sangsiriwut, K., Pooruk, P., Boonnak, K., Khanyok, R., Thawachsupa, P., Kijphati, R., and Sawanpanyalert, P., 2005, Molecular characterization of the complete genome of human influenza H5N1 virus isolates from Thailand. J Gen Virol 86, 423-33.

Ramanathan, R. K., Potter, D. M., Belani, C. P., Jacobs, S. A., Gravenstein, S., Lim, F., Kim, H., Savona, S., Evans, T., Buchbarker, D., Simon, M. B., Depee, J. K., and Trump, 
D. L., 2002, Randomized trial of influenza vaccine with granulocyte-macrophage colony-stimulating factor or placebo in cancer patients. J Clin Oncol 20, 4313-8.

Razvi, E. S., and Welsh, R. M., 1995, Apoptosis in viral infections. Adv Virus Res 45, 1-60.

Rimmelzwaan, G. F., Baars, M., van Amerongen, G., van Beek, R., and Osterhaus, A. D., 2001, A single dose of an ISCOM influenza vaccine induces long-lasting protective immunity against homologous challenge infection but fails to protect Cynomolgus macaques against distant drift variants of influenza A (H3N2) viruses. Vaccine 20, 158-63.

Roche, 2001, Tamiflu ${ }^{\mathrm{TM}}$ patient information.

Romanova, J., Katinger, D., Ferko, B., Vcelar, B., Sereinig, S., Kuznetsov, O., Stukova, M., Erofeeva, M., Kiselev, O., Katinger, H., and Egorov, A., 2004, Live cold-adapted influenza A vaccine produced in Vero cell line. Virus Res 103, 187-93.

Root, C. N., Wills, E. G., McNair, L. L., and Whittaker, G. R., 2000, Entry of influenza viruses into cells is inhibited by a highly specific protein kinase $\mathrm{C}$ inhibitor. $J$ Gen Virol 81, 2697-705.

Rott, O., Charreire, J., Semichon, M., Bismuth, G., and Cash, E., 1995, B cell superstimulatory influenza virus (H2-subtype) induces B cell proliferation by a PKCactivating, $\mathrm{Ca}(2+)$-independent mechanism. J Immunol 154, 2092-103.

Savarino, A., 2005, Expanding the frontiers of existing antiviral drugs: Possible effects of HIV-1 protease inhibitors against SARS and avian influenza. J Clin Virol.

Schickli, J. H., Flandorfer, A., Nakaya, T., Martinez-Sobrido, L., Garcia-Sastre, A., and Palese, P., 2001, Plasmid-only rescue of influenza A virus vaccine candidates. Philos Trans R Soc Lond B Biol Sci 356, 1965-73.

Scholtissek, C., and Faulkner, G. P., 1979, Amantadine-resistant and -sensitive influenza A strains and recombinants. J Gen Virol 44, 807-815.

Schultz-Cherry, S., and Hinshaw, V. S., 1996, Influenza virus neuraminidase activates latent transforming growth factor beta. $J$ Virol 70, 8624-9.

Schultz-Cherry, S., Krug, R. M., and Hinshaw, V. S., 1998, Induction of apoptosis by influenza virus. Semin Virol 8, 491-495.

Sebolt-Leopold, J. S., Dudley, D. T., Herrera, R., Van Becelaere, K., Wiland, A., Gowan, R. C., Tecle, H., Barrett, S. D., Bridges, A., Przybranowski, S., Leopold, W. R., and Saltiel, A. R., 1999, Blockade of the MAP kinase pathway suppresses growth of colon tumors in vivo. Nat Med 5, 810-6.

Seo, S. H., Goloubeva, O., Webby, R., and Webster, R. G., 2001, Characterization of a porcine lung epithelial cell line suitable for influenza virus studies. Journal of Virology 75, 9517.

Sieczkarski, S. B., Brown, H. A., and Whittaker, G. R., 2003, Role of protein kinase C betaII in influenza virus entry via late endosomes. J Virol 77, 460-9.

Sieczkarski, S. B., and Whittaker, G. R., 2002, Dissecting virus entry via endocytosis. J Gen Virol 83, 1535-45.

Slee, E. A., Adrain, C., and Martin, S. J., 1999, Serial killers: ordering caspase activation events in apoptosis. Cell Death Differ 6, 1067-74.

Smee, D. F., Huffman, J. H., Morrison, A. C., Barnard, D. L., and Sidwell, R. W., 2001, Cyclopentane neuraminidase inhibitors with potent in vitro anti-influenza virus activities. Antimicrob Agents Chemother 45, 743-8. 
Stepanova, L., Naykhin, A., Kolmskog, C., Jonson, G., Barantceva, I., Bichurina, M., Kubar, O., and Linde, A., 2002, The humoral response to live and inactivated influenza vaccines administered alone and in combination to young adults and elderly. $J$ Clin Virol 24, 193-201.

Stephenson, I., Nicholson, K. G., Wood, J. M., Zambon, M. C., and Katz, J. M., 2004, Confronting the avian influenza threat: vaccine development for a potential pandemic. Lancet Infect Dis 4, 499-509.

Subbarao, K., Chen, H., Swayne, D., Mingay, L., Fodor, E., Brownlee, G., Xu, X., Lu, X., Katz, J., Cox, N., and Matsuoka, Y., 2003, Evaluation of a genetically modified reassortant $\mathrm{H} 5 \mathrm{~N} 1$ influenza A virus vaccine candidate generated by plasmid-based reverse genetics. Virology 305, 192-200.

Subbarao, K., Klimov, A., Katz, J., Regnery, H., Lim, W., Hall, H., Perdue, M., Swayne, D., Bender, C., Huang, J., Hemphill, M., Rowe, T., Shaw, M., Xu, X., Fukuda, K., and Cox, N., 1998, Characterization of an avian influenza A (H5N1) virus isolated from a child with a fatal respiratory illness. Science 279, 393-6.

Swierkosz, E. M., Newman, F. K., Anderson, E. L., Nugent, S. L., Mills, G. B., and Belshe, R. B., 1994, Multidose, live attenuated, cold-recombinant, trivalent influenza vaccine in infants and young children. $J$ Infect Dis 169, 1121-4.

Takahashi, K., Furuta, Y., Fukuda, Y., Kuno, M., Kamiyama, T., Kozaki, K., Nomura, N., Egawa, H., Minami, S., and Shiraki, K., 2003, In vitro and in vivo activities of T-705 and oseltamivir against influenza virus. Antivir Chem Chemother 14, 235-41.

Takizawa, T., Fukuda, R., Miyawaki, T., Ohashi, K., and Nakanishi, Y., 1995, Activation of the apoptotic Fas antigen-encoding gene upon influenza virus infection involving spontaneously produced beta-interferon. Virology 209, 288-96.

Takizawa, T., Matsukawa, S., Higuchi, Y., Nakamura, S., Nakanishi, Y., and Fukuda, R., 1993, Induction of programmed cell death (apoptosis) by influenza virus infection in tissue culture cells. J Gen Virol 74, 2347-55.

Takizawa, T., Ohashi, K., and Nakanishi, Y., 1996, Possible involvement of double-stranded RNA-activated protein kinase in cell death by influenza virus infection. $J$ Virol 70, 8128-32.

Takizawa, T., Tatematsu, C., Ohashi, K., and Nakanishi, Y., 1999, Recruitment of apoptotic cysteine proteases (caspases) in influenza virus-induced cell death. Microbiol Immunol 43, 245-52.

Talon, J., Salvatore, M., O’Neill, R. E., Nakaya, Y., Zheng, H., Muster, T., Garcia-Sastre, A., and Palese, P., 2000, Influenza A and B viruses expressing altered NS1 proteins: A vaccine approach. Proc Natl Acad Sci US A 97, 4309-14.

Tamura, S., and Kurata, T., 2004, Defense Mechanisms against Influenza Virus Infection in the Respiratory Tract Mucosa. Jpn. J. Infect. Dis. 57, 236-247.

Taniguchi, T., and Takaoka, A., 2002, The interferon-alpha/beta system in antiviral responses: a multimodal machinery of gene regulation by the IRF family of transcription factors. Curr Opin Immunol 14, 111-6.

Taubenberger, J. K., Reid, A. H., and Fanning, T. G., 2000, The 1918 influenza virus: A killer comes into view. Virology 274, 241-5.

Thanos, D., and Maniatis, T., 1995, Virus induction of human IFN beta gene expression requires the assembly of an enhanceosome. Cell 83, 1091-100.

Thornberry, N. A., and Lazebnik, Y., 1998, Caspases: enemies within. Science 281, 1312-6. 
Tisdale, M., 2000: Monitoring of viral susceptibility: new challenges with the development of influenza NA inhibitors. Rev Med Virol 10, 45-55.

Toker, A., 1998, Signaling through protein kinase C. Front Biosci 3, D1134-47.

Tomassini, J., Selnick, H., Davies, M. E., Armstrong, M. E., Baldwin, J., Bourgeois, M., Hastings, J., Hazuda, D., Lewis, J., McClements, W., and et al., 1994, Inhibition of cap $(\mathrm{m} 7 \mathrm{GpppXm})$-dependent endonuclease of influenza virus by 4-substituted 2,4dioxobutanoic acid compounds. Antimicrob Agents Chemother 38, 2827-37.

Tomassini, J. E., 1996, Expression, purification, and characterization of orthomyxovirus: influenza transcriptase. Methods Enzymol 275, 90-9.

Tominack, R. L., and Hayden, F. G., 1987, Rimantadine hydrochloride and amantadine hydrochloride use in influenza A virus infections. Infect Dis Clin North Am 1, 459478.

Townsend, A., Bastin, J., Bodmer, H., Brownlee, G., Davey, J., Gotch, F., Gould, K., Jones, I., McMichael, A., Rothbard, J., and et al., 1989, Recognition of influenza virus proteins by cytotoxic T lymphocytes. Philos Trans R Soc Lond B Biol Sci 323, 52733.

Treanor, J. J., and Betts, R. F., 1998, Evaluation of live, cold-adapted influenza A and B virus vaccines in elderly and high-risk subjects. Vaccine 16, 1756-60.

Treanor, J. J., Hayden, F. G., Vrooman, P. S., Barbarash, R., Bettis, R., Riff, D., Singh, S., Kinnersley, N., Ward, P., and Mills, R. G., 2000, Efficacy and safety of the oral neuraminidase inhibitor oseltamivir in treating acute influenza: a randomized controlled trial. US Oral Neuraminidase Study Group. Jama 283, 1016-1024.

Treanor, J. J., Kotloff, K., Betts, R. F., Belshe, R., Newman, F., Iacuzio, D., Wittes, J., and Bryant, M., 1999, Evaluation of trivalent, live, cold-adapted (CAIV-T) and inactivated (TIV) influenza vaccines in prevention of virus infection and illness following challenge of adults with wild-type influenza A (H1N1), A (H3N2), and B viruses. Vaccine 18, 899-906.

Treanor, J. J., Mattison, H. R., Dumyati, G., Yinnon, A., Erb, S., O’Brien, D., Dolin, R., and Betts, R. F., 1992, Protective efficacy of combined live intranasal and inactivated influenza A virus vaccines in the elderly. Ann Intern Med 117, 625-33.

Tree, J. A., Richardson, C., Fooks, A. R., Clegg, J. C., and Looby, D., 2001, Comparison of large-scale mammalian cell culture systems with egg culture for the production of influenza virus A vaccine strains. Vaccine 19, 34-44.

Tumpey, T. M., Lu, X., Morken, T., Zaki, S. R., and Katz, J. M., 2000, Depletion of lymphocytes and diminished cytokine production in mice infected with a highly virulent influenza A (H5N1) virus isolated from humans. $J$ Virol 74, 6105-16.

Van Campen, H., Easterday, B. C., and Hinshaw, V. S., 1989a, Destruction of lymphocytes by a virulent avian influenza A virus. $J$ Gen Virol 70, 467-72.

Van Campen, H., Easterday, B. C., and Hinshaw, V. S., 1989b, Virulent avian influenza A viruses: their effect on avian lymphocytes and macrophages in vivo and in vitro. $J$ Gen Virol 70, 2887-95.

Varghese, J. N., Laver, W. G., and Colman, P. M., 1983, Structure of the influenza virus glycoprotein antigen neuraminidase at 2.9 A resolution. Nature 303, 35-40.

Varghese, J. N., McKimm-Breschkin, J. L., Caldwell, J. B., Kortt, A. A., and Colman, P. M., 1992, The structure of the complex between influenza virus neuraminidase and sialic acid, the viral receptor. Proteins 14, 327-332. 
Varghese, J. N., Smith, P. W., Sollis, S. L., Blick, T. J., Sahasrabudhe, A., McKimmBreschkin, J. L., and Colman, P. M., 1998, Drug design against a shifting target: a structural basis for resistance to inhibitors in a variant of influenza virus neuraminidase. Structure 6, 735-746.

von Itzstein, M., Wu, W. Y., Kok, G. B., Pegg, M. S., Dyason, J. C., Jin, B., Van Phan, T., Smythe, M. L., White, H. F., Oliver, S. W., and et al,. 1993, Rational design of potent sialidase-based inhibitors of influenza virus replication. Nature 363, 418423.

Wada, N., Matsumura, M., Ohba, Y., Kobayashi, N., Takizawa, T., and Nakanishi, Y., 1995, Transcription stimulation of the Fas-encoding gene by nuclear factor for interleukin-6 expression upon influenza virus infection. J Biol Chem 270, 18007-12.

Wagner, R., Wolff, T., Herwig, A., Pleschka, S., and Klenk, H. D., 2000, Interdependence of hemagglutinin glycosylation and neuraminidase as regulators of influenza virus growth: a study by reverse genetics. $J$ Virol 74, 6316-6323.

Wang, X., Li, M., Zheng, H., Muster, T., Palese, P., Beg, A. A., and Garcia-Sastre, A., 2000, Influenza A virus NS1 protein prevents activation of NF-kappaB and induction of alpha/beta interferon. $J$ Virol 74, 11566-73.

Wareing, M. D., and Tannock, G. A., 2001, Live attenuated vaccines against influenza; an historical review. Vaccine 19, 3320-30.

Watanabe, T., Watanabe, S., Kida, H., and Kawaoka, Y., 2002a, Influenza A virus with defective M2 ion channel activity as a live vaccine. Virology 299, 266-70.

Watanabe, T., Watanabe, S., Neumann, G., Kida, H., and Kawaoka, Y., 2002b, Immunogenicity and protective efficacy of replication-incompetent influenza viruslike particles. $J$ Virol 76, 767-73.

Webby, R. J., and Webster, R. G., 2003, Are we ready for pandemic influenza? Science 302, 1519-22.

Webster, R. G., 1997a Influenza virus: transmission between species and relevance to emergence of the next human pandemic. Arch Virol Suppl 13, 105-13.

Webster, R. G., 1997b Predictions for future human influenza pandemics. J Infect Dis 176 Suppl 1, S14-9.

Webster, R. G., 1999, 1918 Spanish influenza: the secrets remain elusive. Proc Natl Acad Sci U $A$ A 96, 1164-6.

Webster, R. G., Bean, W. J., Gorman, O. T., Chambers, T. M., and Kawaoka, Y., 1992, Evolution and ecology of influenza A viruses. Microbiol Rev 56, 152-79.

Webster, R. G., Sharp, G. B., and Claas, E. C., 1995, Interspecies transmission of influenza viruses. Am J Respir Crit Care Med 152, S25-30.

Webster, R. G., Shortridge, K. F., and Kawaoka, Y., 1997, Influenza: interspecies transmission and emergence of new pandemics. FEMS Immunol Med Microbiol 18, 275-9.

Welliver, R., Monto, A. S., Carewicz, O., Schatteman, E., Hassman, M., Hedrick, J., Jackson, H. C., Huson, L., Ward, P., and Oxford, J. S., 2001, Effectiveness of oseltamivir in preventing influenza in household contacts: a randomized controlled trial. Jama 285, 748-754.

Widmann, C., Gibson, S., Jarpe, M. B., and Johnson, G. L., 1999, Mitogen-activated protein kinase: conservation of a three-kinase module from yeast to human. Physiol Rev 79, 143-80. 
Wilschut, J., and McElhaney, J. E., 2005, Influenza. Mosby Elsevier Limited.

Windon, R. G., Chaplin, P. J., McWaters, P., Tavarnesi, M., Tzatzaris, M., Kimpton, W. G., Cahill, R. N., Beezum, L., Coulter, A., Drane, D., Sjolander, A., Pearse, M., Scheerlinck, J. P., and Tennent, J. M., 2001, Local immune responses to influenza antigen are synergistically enhanced by the adjuvant ISCOMATRIX. Vaccine $\mathbf{2 0}$, 490-7.

Wolff, J. A., Malone, R. W., Williams, P., Chong, W., Acsadi, G., Jani, A., and Felgner, P. L., 1990, Direct gene transfer into mouse muscle in vivo. Science 247, 1465-8.

Woodland, D. L., Hogan, R. J., and Zhong, W., 2001, Cellular immunity and memory to respiratory virus infections. Immunol Res 24, 53-67.

Woods, J. M., Bethell, R. C., Coates, J. A., Healy, N., Hiscox, S. A., Pearson, B. A., Ryan, D. M., Ticehurst, J., Tilling, J., Walcott, S. M., and et al., 1993, 4-Guanidino-2,4dideoxy-2,3-dehydro-N-acetylneuraminic acid is a highly effective inhibitor both of the sialidase (neuraminidase) and of growth of a wide range of influenza A and B viruses in vitro. Antimicrob Agents Chemother 37, 1473-1479.

World Health Organization, 2005, Communicable Disease Surveillance \& Response (CSR). Avian Influenza.

Woronicz, J. D., Gao, X., Cao, Z., Rothe, M., and Goeddel, D. V., 1997, IkappaB kinase-beta: NF-kappaB activation and complex formation with IkappaB kinase-alpha and NIK. Science 278, 866-9.

Wright, P. F., and Webster, R. G., 2001, Orthomyxoviruses, pp. 1533-1579. In D. M. Knipe, P. M. Howley, and D. E. Griffin (Eds): Fields Virology, Lippencott Williams \& Williams.

Wurzer, W. J., Ehrhardt, C., Pleschka, S., Berberich-Siebelt, F., Wolff, T., Walczak, H., Planz, O., and Ludwig, S., 2004, NF-kappaB-dependent induction of tumor necrosis factor-related apoptosis-inducing ligand (TRAIL) and Fas/FasL is crucial for efficient influenza virus propagation. J Biol Chem 279, 30931-7.

Wurzer, W. J., Planz, O., Ehrhardt, C., Giner, M., Silberzahn, T., Pleschka, S., and Ludwig, S., 2003, Caspase 3 activation is essential for efficient influenza virus propagation. Embo J 22, 2717-28.

Yoneyama, M., Suhara, W., Fukuhara, Y., Fukuda, M., Nishida, E., and Fujita, T., 1998, Direct triggering of the type I interferon system by virus infection: activation of a transcription factor complex containing IRF-3 and CBP/p300. Embo J 17, 1087-95.

Youil, R., Su, Q., Toner, T. J., Szymkowiak, C., Kwan, W. S., Rubin, B., Petrukhin, L., Kiseleva, I., Shaw, A. R., and DiStefano, D., 2004, Comparative study of influenza virus replication in Vero and MDCK cell lines. Journal of Virological Methods 120, 23.

Zamanian-Daryoush, M., Mogensen, T. H., DiDonato, J. A., and Williams, B. R., 2000, NFkappaB activation by double-stranded-RNA-activated protein kinase (PKR) is mediated through NF-kappaB-inducing kinase and IkappaB kinase. Mol Cell Biol 20, 1278-90.

Zambon, M., and Hayden, F. G., 2001, Position statement: global neuraminidase inhibitor susceptibility network. Antiviral Res 49, 147-156.

Zhirnov, O. P., Konakova, T. E., Garten, W., and Klenk, H., 1999, Caspase-dependent Nterminal cleavage of influenza virus nucleocapsid protein in infected cells. $J$ Virol 73, 10158-63. 
Zhirnov, O. P., Ovcharenko, A. V., Bukrinskaia, A. G., Ursaki, L. P., and Ivanova, L. A., 1984, [Antiviral and therapeutic action of protease inhibitors in viral infections: experimental and clinical observations]. Vopr Virusol 29, 491-7.

Zurbriggen, R., 2003, Immunostimulating reconstituted influenza virosomes. Vaccine 21, 921-4. 